\title{
Green synthesis of iron oxide nanoparticles for biomedical application and environmental remediation: a review
}

Sunday Adewale Akintelu ${ }^{1,2} \oplus$, Abel Kolawole Oyebamiji ${ }^{2,3}$, Seyifunmi Charles Olugbeko ${ }^{4}$, Aderonke Similoluwa Folorunso ${ }^{5+}$ (i)

1. Beijing Institute of Technology, School of Chemistry and Chemical Engineering, Beijing, China.

2. Ladoke Akintola University of Technology, Department of Pure and Applied Chemistry, Ogbomoso, Nigeria.

3. Adeleke University, Department of Basic Sciences, Ede, Nigeria.

4. Ladoke Akintola University of Technology, Department of Agricultural Economics, Ogbomoso, Nigeria.

5. Louisiana State University, Department of Chemistry, Louisiana, United States of America.

+Corresponding author: Aderonke Similoluwa Folorunso, Phone: +2348136872649, Email address: folorunsoaderonkesimi@gmail.com

\section{ARTICLE INFO}

Article history:

Received: July 20, 2020

Accepted: March 17, 2021

Published: October 01, 2021
Keywords

1. biosynthesis

2. characterization techniques

3. optimization

4. plant

Section Editor: Assis Vicente Benedetti

ABSTRACT: Ferrous oxide nanoparticles (IONPs) formed from plant materials have been considered as chemically friendly materials and have offered extensive applications. The distinctive features of IONPs, such as biocompatibility, low toxicity, catalytic behavior and multi reaction mechanism, have embodied them as good candidate for several biomedical applications. However, the synthesis of IONPs using plant extracts is gaining high popularity and recommendations because plant extracts could act as reducing and stabilizing agents during the process of synthesis. Furthermore, the biological method of synthesizing IONPs using plant extract offer some benefits, such as being simple, economic, environmentally friendly and require less energy when compared with both physical

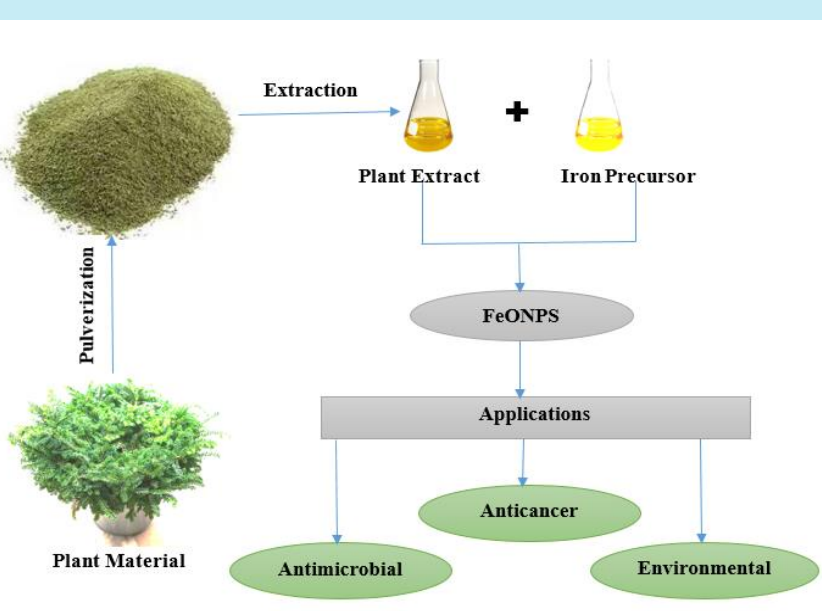
and chemical methods of synthesis. Hence, this review significantly summarized the synthesis, optimum conditions and characterization techniques involved in the synthesis of IONPs using several plant extracts. Consequently, comprehensive information about the applications of green synthesized IONPs as antimicrobial and anticancer therapeutic agents were well presented. The effectiveness of IONPs in environmental treatment of effluent containing dyes and other toxic agents were also properly discussed. 


\section{CONTENTS}

1. Introduction

2. Synthesis of IONPs

2.1 Physical methods

2.2 Chemical methods

2.3 Biological method

2.3.1 Microorganism based IONPs synthesis

2.3.2 Plant based IONPs synthesis

2.4 Possible mechanism for the synthesis of IONPS

3. Optimization

3.1 Effect of precursor

3.2 Effect of concentration of precursor

3.3 Effect of $\mathrm{pH}$

3.4 Effect of temperature

3.5 Time or reaction and incubation

3.6 Effect of type of plant extracts and concentrations of on IONPs synthesis

\section{Introduction}

Nanoscience and nanotechnology have emerged as an innovative field of research with numerous applications in technological and scientific aspects including medical sciences, applied sciences, material science, catalysis, electronics, biofilm and biotechnology (Assa et al., 2016). The smaller sizes of nanoparticles (NPs) compared with large biomolecules have been reported to enhance their interactions with several biological molecules, which may revolutionize microbial treatment and cancer diagnosis (Alharbi and Al-sheikh, 2014). Among the various kinds of metals and metal oxides NPs, iron oxide NPs are one of the most prominent metal oxide NPs. The exceptional attribute of ferrous oxide nanoparticles (IONPs) has widened its horizon and applications in medical sciences and many other industries, such as gas sensor, electrochemical, magnetic and energy storage (Vallabani and Singh, 2018). The superparamagnetic behavior of iron oxide NPs has promoted its extensive applications in several areas, such as imaging, drug delivery, targeting and biosensors. Furthermore, their unique properties, such as biocompatibility, potent magnetic, low toxicity and catalytic behavior, have contributed massively to its biomedical applications (Vallabani and Singh, 2018). Various types of IONPs, such as maghemite $\left(\gamma-\mathrm{Fe}_{2} \mathrm{O}_{3}\right)$ hematite $\left(\alpha-\mathrm{Fe}_{2} \mathrm{O}_{3}\right)$ and magnetite $\left(\mathrm{Fe}_{3} \mathrm{O}_{3}\right)$ NPs, have been reported as efficient therapeutic agents against several infections due to their morphological properties (Yadav and Fulekar, 2018). Physical and chemical methods like chemical precipitation, mineralization, sol-gel, flow injection,
4. Characterization techniques

4.1 Nanoparticle formation analysis

4.2 Functional group identification

4.3 Morphological assessment of IONPs

4.3.1 Transmission electron microscope (TEM)

4.3.2 Scanning electron microscopy (SEM)

4.3.3 Atomic force microscopy (AFM)

4.3.4 Elemental composition

4.3.4.1 Energy dispersive X-ray spectra (EDX)

4.3.4.2 Crystallinity evaluation

5. Applications of IONPs synthesized from plant extract

5.1 Antimicrobial applications

5.2 Anticancer applications

5.3 Environmental application

6. Conclusion

microemulsion, hydrothermal technique, biomimetic precipitation, forced hydrolysis technique, sonochemical technique and electrochemical technique have been chosen for the synthesis of IONPs (Gebre and Sendeku, 2019). The biological methods of synthesizing metal and metal oxides have been regarded as the most preferred method due to its costeffectiveness, safety and easy protocol of synthesis (El Shafey, 2020). However, the biological method of synthesizing IONPs is classified into two main parts; the first category involves the use of microorganisms such as algae, bacteria and fungi as reducing agent while the other form entails the use of plant extracts as reducing and stabilizing agents (Salem et al., 2019; Yew et al., 2020). The capability of plant extracts to function as good reducing and stabilizing agents by reducing particle size and improve reactivity was contributed to the general acceptance of biological synthesis of metal and metal oxides from plant sources (Akintelu and Folorunso, 2019a; Akintelu et al., 2019a; Bashir et al., 2019; Folorunso et al., 2019). Plant extracts used for the synthesis of metal and metal oxides have been reported to show better stability and more acquiescent to large scale production of NPs when compared with the biological approach of synthesis that uses microorganisms (Akintelu and Folorunso, 2019b; Akintelu et al., 2019b; Kamran et al., 2019). The effectiveness of plants extracts as good reducing and stabilizing agents are linked with the presence of biomolecules such as flavonoids, alkaloids, terpenoids, and other hydroxyl containing functional groups which coat the surface of the NPs, prevent agglomeration and aid the production of NPs with uniform particle size (Gunarani et al., 2019). 
Therefore, this review primarily focuses on the recent developments in the biosynthesis of IONPs using plant extracts. The various methods used for the synthesis of IONPs were briefly discussed. The mechanism of formation of IONPs using plant extract, the techniques used for the characterization of IONPs were highlighted. Then, the application of biosynthesized IONPs in the biomedicine and environmental waste management is summarized.

\section{Synthesis of IONPs}

Many reports have shown that the application of IONPs depend largely on the method of synthesis used (Arsalani et al., 2019). The preparation method determines the size distribution, particle sizes, shape and surface morphology which further influenced their applications. Moreover, the preparation method has been reported as the determinant factor for the degree of structural defects and impurity level of IONPs (Roca et al., 2019). Several methods and protocols such as physical, chemical and biological have been designed for the synthesis of IONPs with desired morphological features and magnetic properties (Palma et al., 2018).

\subsection{Physical methods}

Physical methods are based on the use of electrical fields and some other physical phenomena as the reducing agent during the synthesis of IONPs. The most reoccurring one is particle growth, which is based on physical processes and top-down approach. Examples of such techniques are sonochemical, lithography, sputtering, microwaves irradiation and laser ablation. The sonochemical technique encompasses the sonication of an aqueous ferric solution at ambient conditions and in the presence of air (Nisticò, 2021). Ultrasounds generate irregular compression and expansion acoustic waves which cause the oscillation of the microbubbles ( $\mathrm{Wu}$ et al., 2015). When the bubbles collapse a localized hot spot is formed at high temperature around $4500{ }^{\circ} \mathrm{C}$ and pressure of about 1000 bar which enhanced the conversion of iron precursors into IONPs (Pinkas et al., 2008). The IONPs produced via this technique have high stability and remarkable magnetic properties. Despite the aforementioned advantages it is difficult to control the shape of IONPs produced from this technique (Ali et al., 2016).

Microwaves irradiation approach uses an electromagnetic source with wavelength in the range of $1-103 \mathrm{~mm}$ as reducing agent (Nisticò, 2017). The radiation during this process causes molecules to align with the external field to generate motion that produces internal heating. This process has the advantages of reduction in treatment time and energy consumption. Also purified IONPs are mostly obtained. Notwithstanding, a report has revealed that this technique is limited because IONPs produced have poor morphological features and low surface reactivity (Pascu et al., 2012).

The electrochemical technique encompasses the immersion of galvanic cell with two electrodes (usually made up of iron) into a saline solution (Nisticò, 2021). This process involves iron electro-oxidation and electrolysis of water at the anode, alongside water reduction at the cathode. The electrochemical technique is affected by parameters such as working distance between electrodes, $\mathrm{pH}$, reaction time and temperature. These techniques allow easy control of particle size and IONPs with hydrophilic surfaces are usually obtained (Cabrera et al., 2008).

\subsection{Chemical methods}

The chemical approach of synthesizing IONPs depends on the growth of iron oxides from the liquid phase via the use of some chemical reagents. Among the several protocols and techniques used for the chemical method of synthesis such as co-precipitation, micro-emulsion, sol-gel and polyol-mediated technique, co-precipitation technique is the most common and simplest (Lenders et al., 2016; Pang et al., 2016). Co-precipitation entails the stoichiometric mixture of iron precursor in presence of a basic conditions, following the given reaction pathway (Eq. 1).

$2 \mathrm{Fe}^{3+}+\mathrm{Fe}^{2+}+8 \mathrm{OH}^{-} \rightarrow \mathrm{Fe}_{3} \mathrm{O}_{4}+4 \mathrm{H}_{2} \mathrm{O}$

Acidic iron ions $\left(\mathrm{Fe}^{3+}\right.$ or $\left.\mathrm{Fe}^{2+}\right)$ when introduced into basic solution precipitates to form IONPs because magnetite is poorly soluble in basic condition. The formation of magnetite or maghemite NPs using the co-precipitation route depends on the ratio of $\mathrm{Fe}^{3+}$ or $\mathrm{Fe}^{2+}$ used (Nisticò et al., 2017a). The temperature requirement for the co-precipitation route is in the range of (20-250 ${ }^{\circ} \mathrm{C}$ ) (Franzoso et al., 2017; Nisticò, 2017b). The following parameters iron precursor and ratio used, ionic strength, temperature, stirring rate and $\mathrm{pH}$ influences the size and shape of IONPs synthesized via the co-precipitation technique (Yazdani and Seddigh, 2016). Co-precipitation technique has been reported as the famous chemical methods for 
synthesizing IONPs with control size distribution and high yields. However, this process suffers from some disadvantages such as the use of hazardous chemical reagents and difficulties in controlling the shape IONPs (Nisticò et al., 2017a).

The micro-emulsion process is another form of chemical method. In this process iron precursor either in water or oil biphasic system is exploited in the presence of amphiphilic molecules in form of block copolymers or sometimes surfactants such as cetyl trimethyl ammonium bromide or polyvinyl pyrrolidone at the interface (Nisticò, 2017). As a result of the dual nature (i.e., occurrence of both hydrophilic head and hydrophobic tail) of the amphiphiles macro molecules, the species moved at the interface of the two immiscible phases form covalent bonds and also assemble themselves into supramolecular aggregates of various shapes (Nisticò, 2018). The micro-emulsion process has advantages of narrow size IONPs production and easy shape regulation. However, the process has some disadvantages, such as low yield, impure products and formation of agglomeration (Wu et al., 2015).

Sol-gel technique involves acid/based-catalyzed hydrolysis and condensation of precursors from colloidal solutions to produce condensed network of iron oxides (Nisticò et al., 2017b). Iron alkoxides or iron salts are the main precursor for this technique because they can easily react through hydrolysis or condensation to yield oxides (Lemine et al., 2012).

Polyol-mediated technique entail the use of polyols as the reducing and stabilizing agents to aid the shape and size control during the synthesis of IONPs (Nisticò, 2021). This process is based on spreading iron containing precursors such as alkoxides in liquid polyols and heat to its boiling point. A report has shown that IONPs synthesized by polyol-mediated techniques are highly crystalline and can be easily dispersed into polar media due to their hydrophilic surfaces. Conversely, this technique has the limitation of generating toxic byproducts (Wu et al., 2015).

\subsection{Biological method}

The biological method of synthesizing IONPs is classified into two major routes, namely microorganism and plant based IONPs synthesis.

\subsubsection{Microorganism based IONPs synthesis}

Synthesis of IONPs using microorganism has gained huge attention over the past few decades due to some advantages over conventional chemical and physical methods of synthesis. The advantages of microorganism based IONPs synthesis include relative abundance of microorganism, production of less toxic byproducts, consumption of less power and energy because synthesis is carried out at room temperature and it tolerates large scale production (Park et al., 2016). Microorganisms such as bacteria, algae, fungi and yeast have been used for the synthesis of IONPs via intracellular or extracellular mechanism. The intracellular mechanism involves the enzymatic reduction of metal ions or metal oxide ion via electrostatic bounding to the cell wall of microorganism, the ions diffused into the cell and cause some interaction with enzymes to form IONPs (Mukherjee, 2017). The extracellular mechanism entails the enzymatic reduction of iron ions, producing small size distribution and well dispersed NPs with genes, peptides or protein that function as reducing agents, which in turn stabilizes and prevent agglomeration of IONPs (Singh et al., 2016).

\subsubsection{Plant based IONPs synthesis}

This is the process of synthesizing IONPs using extracts obtained from parts of plants, such as back, leaves, root, shoot, stems or the whole plant. In general, the desired plant part is obtained, sorted and washed to remove any impurities (solid or particles), air dried, chopped/mercerized to provide good surface area for extraction (Bolade et al., 2018). The extraction of their chemical constituents is accomplished by soaking the air-dried plant part at room temperature or boiled at elevated temperature to obtain the desired amount of extract (Bolade et al., 2020). This depends on the successful extraction of bioactive constituents in plant extracts. These bioactive constituents (phenols, tannins, saponins, alkaloids, organic acids, flavonoids and vitamins) function as reducing agents during the IONPs synthesis by reacting with the iron precursor (iron chloride, iron nitrate or iron sulphate) to produce IONPs, which are further stabilized by the chemical constituent present in the extract (Sorbiun et al., 2018). Several studies have reported the use of water as extracting solvent in the extraction of bioactive components of plants during the synthesis of IONPs (Prabhakar et al., 2017). Leaves, peel, bark and fruits of green plants have been studied for the eco-friendly synthesis of IONPs, as showed in Tabs. 1 and 2. The methods of synthesizing iron oxide NPs are illustrated in Fig. 1. 
Table 1. Characterization techniques of biosynthesized IONPs from some plant materials.

\begin{tabular}{|c|c|c|c|c|c|c|c|c|c|}
\hline $\mathbf{S} / \mathbf{N}$ & Plants name & $\begin{array}{l}\text { Plants } \\
\text { parts }\end{array}$ & SPR peak/nm & $\begin{array}{r}\text { Ba } \\
\text { Functional }\end{array}$ & prediction & $\begin{array}{c}\text { Techniques for } \\
\text { morphological assessment }\end{array}$ & Shape & Size & References \\
\hline 1 & Punica granatum & Seeds & 372 & - & - & UV, XRD, EDX, SEM, AFM & Spherical & $25-55$ & Bibi et al., 2019 \\
\hline \multirow{3}{*}{2} & \multirow{3}{*}{ Magnifera indica } & \multirow{3}{*}{ Peel } & \multirow{3}{*}{$250-280$} & 3334 & $\mathrm{O}-\mathrm{H}$ & \multirow{3}{*}{ XRD, UV, FTIR, XPS, EDX } & \multirow{3}{*}{-} & \multirow{3}{*}{-} & \multirow{3}{*}{ Desalegn et al., 2019} \\
\hline & & & & 2973 & $\mathrm{C}-\mathrm{H}$ & & & & \\
\hline & & & & 1654 & $\mathrm{C}=\mathrm{O}$ & & & & \\
\hline \multirow{2}{*}{3} & \multirow{2}{*}{ Cynara cardunculus } & \multirow{2}{*}{ Leaf } & \multirow{2}{*}{-} & 3306 & $\mathrm{O}-\mathrm{H}$ & \multirow{2}{*}{ UV-Vis, XRD, FTIR, SEM } & \multirow{2}{*}{ Semi-spherical } & \multirow{2}{*}{13.5} & \multirow{2}{*}{ Ruíz-Baltazar et al., 2019} \\
\hline & & & & 1585 & $\mathrm{C}=\mathrm{C}$ & & & & \\
\hline 4 & Tamarix aphylla & Stem & 390 & - & - & XRD, UV, SEM-EDX, TEM & Spherical & - & Ahmad et al., 2020 \\
\hline 5 & K. alvarezii & Whole plant & 457 & 1480 & $\mathrm{O}-\mathrm{H}$ & $\begin{array}{c}\text { XRD, UV, FTIR, HRSEM, } \\
\text { HRTEM, EDX }\end{array}$ & Hexagonal & $10-30$ & Arularasu et al., 2018 \\
\hline \multirow{3}{*}{6} & \multirow{3}{*}{ Moringa oleifera } & \multirow{3}{*}{ Leaf } & \multirow{3}{*}{448} & 3325 & $\mathrm{O}-\mathrm{H}$ & \multirow{3}{*}{ XRD, FTIR, SEM } & \multirow{3}{*}{ Irregular spherical } & \multirow{3}{*}{$18-20$} & \multirow{3}{*}{ Aisida et al., 2021} \\
\hline & & & & 1618 & $\mathrm{C}=\mathrm{O}$ & & & & \\
\hline & & & & 1401 & $\mathrm{C}-\mathrm{N}$ & & & & \\
\hline \multirow{2}{*}{7} & \multirow{2}{*}{ Amaranthus dubius } & & & 3250 & $\mathrm{O}-\mathrm{H}$ & & & & \\
\hline & & Leat & 214 & 1634 & $\mathrm{C}=\mathrm{O}$ & SEM, XRDUV, FTIR & Oval & $58-530$ & Harshiny et al., 2015 \\
\hline & & & & 2979 & $\mathrm{C}-\mathrm{H}$ & SEM, TEM, XRD, DLS, FT- & & & \\
\hline 8 & Rhamnella gilgitica & Leaf & 341 & 1064 & $\mathrm{C}-\mathrm{N}$ & IR, EDX, UV & Spherical & $21-25$ & lqbal et al., 2020 \\
\hline 9 & Terminalia bellirica & fruit & 300 & $3300-340$ & $\mathrm{O}-\mathrm{H}$ & SEM, TEM, XRD, FTIR, UV & Spherical & 21.32 & Jagadeesan et al., 2019 \\
\hline & & & & 1600 & $\mathrm{C}=\mathrm{O}$ & & & & \\
\hline 10 & Stevia rebaudiana & Leaf & - & - & - & $\begin{array}{c}\text { XRD, HRTEM, Fe-SEM, } \\
\text { XPS, EDX, }\end{array}$ & Spherical & 20 & Khatami et al., 2019 \\
\hline & & & & 3416 & $\mathrm{O}-\mathrm{H}$ & & & & \\
\hline 11 & Centella asiatica & whole plant & - & 1621 & $\mathrm{C}=\mathrm{O}$ & TEM, SEM, FTIR, EDX, & Spherical & $20-40$ & Poka et al., 2019 \\
\hline & & & & 1387 & $\mathrm{C}-\mathrm{N}$ & & & & \\
\hline & & & & 3422 & $\mathrm{O}-\mathrm{H}$ & & & & \\
\hline 12 & Avecinnia marina & Flower & $298-301$ & 2923 & $\mathrm{C}-\mathrm{H}$ & UV, FTIR, XRD & - & 45.09 & $\begin{array}{c}\text { Karpagavinayagam and } \\
\text { Vedhi, } 2019\end{array}$ \\
\hline & & & & 1630 & $\mathrm{C}=\mathrm{O}$ & & & & \\
\hline 13 & Green tea & Leaf & & 3440 & $\mathrm{O}-\mathrm{H}$ & SEM EDS XPS FT-IR & Spherical & 117 & Lin et al 2017 \\
\hline 13 & Green tea & Leaf & & 1629 & $\mathrm{C}=\mathrm{O}$ & & & & \\
\hline 14 & Green tea & Leaf & 550 & - & - & UV, SEM, TEM & Spherical & 4.96 & Liu et al., 2019 \\
\hline & Psidium guavaia & & 315 & $3034-3366$ & $\mathrm{O}-\mathrm{H}$ & & & & \\
\hline 15 & Psidıum guavaja & Leat & 315 & 1669 & $\mathrm{C}=\mathrm{O}$ & FTIR, UV, SEM, XRD & Spherical & - & Madubuonu et al., 2019 \\
\hline & & & & 3645 & $0-\mathrm{H}$ & & & & \\
\hline 16 & haematocephala & leaf & - & 2935 & $\mathrm{C}-\mathrm{H}$ & $\begin{array}{l}\text { EDS } \\
\text { ED-vis, }\end{array}$ & Spherical & 85 & Sirdeshpande et al., 2018 \\
\hline & & & & 1662 & $\mathrm{C}=\mathrm{C}$ & & & & \\
\hline & & & & 3428 & $\mathrm{O}-\mathrm{H}$ & & & & \\
\hline 17 & Trigonella foenum- & Seed & 387 & 2940 & $\mathrm{C}-\mathrm{H}$ & FTIR, UV, SEM, EDX & & $7-14$ & Radini et al. 2018 \\
\hline & graecum & seed & 381 & 1756 & $\mathrm{C}=\mathrm{O}$ & FIIK, UV, SEMI, EDX & & & \\
\hline & & & & 1544 & $\mathrm{~N}-\mathrm{H}$ & & & & \\
\hline
\end{tabular}




\begin{tabular}{|c|c|c|c|c|c|c|c|c|c|}
\hline 18 & Luffa acutangula & Peel & - & 3446 & $\mathrm{O}-\mathrm{H}$ & FTIR, XRD, SEM, EDX & Spherical & $20-35$ & Cheera et al., 2016 \\
\hline \multirow{2}{*}{$\begin{array}{l}18 \\
19\end{array}$} & \multirow{3}{*}{$\begin{array}{l}\text { Luffa acutangula } \\
\text { P. guajava }\end{array}$} & \multirow{2}{*}{$\begin{array}{l}\text { Peel } \\
\text { Leaf }\end{array}$} & \multirow{3}{*}{-} & 2829 & $\mathrm{C}-\mathrm{H}$ & \multirow{3}{*}{$\begin{array}{l}\text { FTIR, XRD, SEM, EDX } \\
\text { XRD, SEM, TEM, HRTEM, } \\
\text { EDX, FTIR }\end{array}$} & \multirow{3}{*}{$\begin{array}{l}\text { Spherical } \\
\text { Irregular }\end{array}$} & \multirow{3}{*}{$\begin{array}{l}20-35 \\
20-30\end{array}$} & \multirow{3}{*}{$\begin{array}{l}\text { Cheera et al., } 2016 \\
\text { Rufus et al., } 2019\end{array}$} \\
\hline & & & & 1605 & $\mathrm{C}=\mathrm{C}$ & & & & \\
\hline \multirow[b]{2}{*}{$\begin{array}{l}19 \\
20\end{array}$} & & \multirow[b]{2}{*}{$\begin{array}{l}\text { Leaf } \\
\text { Root }\end{array}$} & & $\begin{array}{l}1410 \\
1640\end{array}$ & $\begin{array}{l}\mathrm{O}-\mathrm{H} \\
\mathrm{C}=\mathrm{O}\end{array}$ & & & & \\
\hline & $\begin{array}{l}\text { P. guajava } \\
\text { Rheum emodi }\end{array}$ & & 320 & 3381 & $\mathrm{O}-\mathrm{H}$ & $\begin{array}{c}\text { XRD, SEM, TEM, HRTEM, } \\
\text { EDX, FTIR } \\
\text { XRD, UV, FESEM, TEM, } \\
\text { EDX, FTIR, AFM, TGA, } \\
\text { VSM }\end{array}$ & $\begin{array}{l}\text { Irregular } \\
\text { Pyramidal }\end{array}$ & $\begin{array}{l}20-30 \\
10-30\end{array}$ & $\begin{array}{l}\text { Rufus et al., } 2019 \\
\text { Sharma et al., } 2020\end{array}$ \\
\hline \multirow{3}{*}{$\begin{array}{l}20 \\
21\end{array}$} & \multirow{3}{*}{$\begin{array}{l}\text { Rheum emodi } \\
\text { Citrus maxima }\end{array}$} & \multirow{3}{*}{$\begin{array}{l}\text { Root } \\
\text { Peel }\end{array}$} & \multirow{3}{*}{$\begin{array}{c}320 \\
-\end{array}$} & 2927 & $\mathrm{C}-\mathrm{H}$ & \multirow{3}{*}{$\begin{array}{c}\text { XRD, UV, FESEM, TEM, } \\
\text { EDX, FTIR, AFM, TGA, } \\
\text { VSM } \\
\text { TEM, EDS, XPS, FTIR, DLS }\end{array}$} & \multirow{3}{*}{$\begin{array}{l}\text { Pyramidal } \\
\text { Irregular }\end{array}$} & \multirow{3}{*}{$\begin{array}{c}10-30 \\
10-100\end{array}$} & \multirow{3}{*}{$\begin{array}{l}\text { Sharma et al., } 2020 \\
\text { Wei et al., } 2016\end{array}$} \\
\hline & & & & 1614 & $\mathrm{C}=\mathrm{O}$ & & & & \\
\hline & & & & 3292 & $\mathrm{O}-\mathrm{H}$ & & & & \\
\hline \multirow{2}{*}{$\begin{array}{l}21 \\
22\end{array}$} & \multirow{2}{*}{$\begin{array}{l}\text { Citrus maxima } \\
\text { Ruellia tuberosa }\end{array}$} & \multirow{2}{*}{$\begin{array}{l}\text { Peel } \\
\text { Leaf }\end{array}$} & \multirow{2}{*}{$\begin{array}{c}- \\
405\end{array}$} & 2927 & C-H & \multirow{2}{*}{$\begin{array}{l}\text { TEM, EDS, XPS, FTIR, DLS } \\
\text { DLS, UV, SEM-EDX, TEM, } \\
\text { FTIR }\end{array}$} & \multirow{2}{*}{$\begin{array}{l}\text { Irregular } \\
\text { Rod }\end{array}$} & \multirow{2}{*}{$\begin{array}{c}10-100 \\
20-80\end{array}$} & \multirow{2}{*}{$\begin{array}{c}\text { Wei et al., } 2016 \\
\text { Vasantharaj et al., } 2019\end{array}$} \\
\hline & & & & $\begin{array}{l}1638 \\
3397\end{array}$ & $\begin{array}{l}\mathrm{C}=\mathrm{O} \\
\mathrm{O}-\mathrm{H}\end{array}$ & & & & \\
\hline \multirow{3}{*}{$\begin{array}{l}22 \\
23\end{array}$} & \multirow{3}{*}{$\begin{array}{l}\text { Ruellia tuberosa } \\
\text { Lawsonia inermis }\end{array}$} & \multirow{3}{*}{$\begin{array}{c}\text { Leaf } \\
\text { Whole plant }\end{array}$} & \multirow{3}{*}{$\begin{array}{l}405 \\
224\end{array}$} & 1629 & $\mathrm{~N}-\mathrm{H}$ & \multirow{3}{*}{$\begin{array}{c}\text { DLS, UV, SEM-EDX, TEM, } \\
\text { FTIR } \\
\text { UV, SEM-EDX, FTIR }\end{array}$} & & & Vasantharaj et al., 2019 \\
\hline & & & & 1114 & $\mathrm{C}=\mathrm{O}$ & & Rod & $20-80$ & Chauhan and Upadhyay, \\
\hline & & & & 3444 & $\mathrm{O}-\mathrm{H}$ & & & & 2019 \\
\hline & & & & 2962 & $\mathrm{C}-\mathrm{H}$ & & & & \\
\hline 23 & Lawsonia inermis & Whole plant & 224 & 1606 & $\mathrm{~N}-\mathrm{H}$ & UV, SEM-EDX, FTIR & Spherical & $150-200$ & 2019 \\
\hline
\end{tabular}

Note. Thermogravimetric analysis (TGA), vibrating sample magnetometer (VSM), and atomic force microscopy (AFM). 
Table 2. Applications of IONPs synthesized from plants extracts.

\begin{tabular}{|c|c|c|c|c|c|c|}
\hline $\mathbf{S} / \mathbf{N}$ & Plants name & Plants part & Iron precursor & Applications & Activities & References \\
\hline 1 & $\begin{array}{l}\text { Parkia speciosa } \\
\quad \text { Hassk }\end{array}$ & Pod & $\mathrm{FeSO}_{4}$ & Photocatalytic activity & $\begin{array}{l}\text { The results imply that the nanoparticles have potential use as } \\
\text { photocatalysts, with applications in dye-containing wastewater } \\
\text { degradation }\end{array}$ & Fatimah et al., 2020 \\
\hline 2 & Eucalyptus robusta & Leaf & $\mathrm{FeSO}_{4}$ & Antibacterial activity & $\begin{array}{l}\text { The result potential antibacterial activity against tested organism, but } \\
\text { more effectiveness was observed against gram positive bacteria (B. } \\
\text { subtilis) }\end{array}$ & Vitta et al., 2020 \\
\hline 3 & Skimma laureola & Leaf & $\mathrm{FeCl}_{3}$ & Antibacterial activity & $\begin{array}{l}\text { The result revealed the importance of biosynthesized } \mathrm{Fe}_{2} \mathrm{O}_{3}-\mathrm{NPs} \text { against } \\
\text { phytopathogen Ralstonia solanacearum in vitro and in plant }\end{array}$ & Alam et al., 2019 \\
\hline 4 & Green and black tea & Leaf & $\mathrm{FeCl}_{3}$ & Antimicrobial activity & $\begin{array}{l}\text { These results showed that the synthesized NPs could be effective against } \\
\text { infections caused by multiple drug resistant pathogens }\end{array}$ & Asghar et al., 2018 \\
\hline 5 & Eucalyptus & Leaf & $\mathrm{FeCl}_{3}$ & Phosphate removal & $\begin{array}{l}\text { The study demonstrated that the formation of IONPs improved the } \\
\text { efficiency of phosphate removal }\end{array}$ & Gan et al., 2018 \\
\hline 6 & Amaranthus dubius & Leaf & $\mathrm{FeCl}_{3}$ & Antibacterial activity & $\begin{array}{l}\text { The study showed that IONPs enhanced the performance of microbial } \\
\text { fuel cell }\end{array}$ & Harshiny et al., 2017 \\
\hline 7 & plantain & Peel & $\mathrm{FeCl}_{3}$ & Catalytic activity & $\begin{array}{l}\text { The study demonstrates an eco-friendly approach to synthesizing IONPs } \\
\text { as a good bio-catalyst for the treatment of effluent waste of industries }\end{array}$ & Buiyan et al., 2020 \\
\hline 8 & Green tea & Leaf & $\mathrm{FeCl}_{3}$ & $\begin{array}{l}\text { Organic pollutant } \\
\text { remediation }\end{array}$ & $\begin{array}{l}\text { The particles showed effective catalytic activity for removal of organic } \\
\text { contaminants }\end{array}$ & Kheshtzar et al., 2019 \\
\hline 9 & Eucalyptus & Leaf & $\mathrm{FeCl}_{3}$ & Catalytic activity & It displayed good efficiency in removing $\mathrm{Cr}(\mathrm{VI})$ & Liu et al., 2018 \\
\hline 10 & Papaver somniferum & Pod & $\mathrm{FeSO}_{4}$ & anti-cancer activity & $\mathrm{Fe}_{2} \mathrm{O}_{3}$ NPs displayed superior biocompatibility with human RBCs & Muhammad et al., 2019 \\
\hline 11 & Chinese cabbage & Leaf & $\mathrm{FeCl}_{2}$ & Antioxidant & $\begin{array}{l}\text { The IONPs showed good synergistic antibacterial, anticandidal and } \\
\text { antioxidant activity }\end{array}$ & Patra and Baek, 2017 \\
\hline 12 & Aloe vera & Leaf & $\mathrm{FeCl}_{2}$ & anti-cancer activity & $\begin{array}{l}\text { The study reported important in vitro cytotoxicity assessments on MCF-7 } \\
\text { breast cancer cell line }\end{array}$ & Rahmani et al., 2020 \\
\hline 13 & Amaranthus spinosus & Leaf & $\mathrm{FeCl}_{3}$ & $\begin{array}{l}\text { Environmental } \\
\text { remediation activities }\end{array}$ & $\begin{array}{l}\text { The IONPs displayed a strong catalytic activity for decolorization of } \\
\text { methylene blue and methyl orange }\end{array}$ & $\begin{array}{l}\text { Muthukumar and } \\
\text { Matheswaran, } 2015\end{array}$ \\
\hline 14 & Pisidium guajava & Leaf & $\mathrm{FeCl}_{3}$ & Antibacterial & $\begin{array}{l}\text { It is noteworthy that the biosynthesized IONPs are more efficient } \\
\text { antibacterial agent }\end{array}$ & Madubuonu et al., 2020 \\
\hline 15 & Murraya koenigii & Leaf & $\mathrm{FeSO}_{4}$ & Hydrogen Production & $\begin{array}{l}\text { The photosynthesized IONPs enhanced the production of hydrogen when } \\
\text { compared with } \mathrm{FeSO}_{4}\end{array}$ & Mohanraj et al., 2014 \\
\hline 16 & Salvadora persica & Bark & $\mathrm{FeSO}_{4}$ & Cytotoxic activity & $\begin{array}{l}\text { The IONPs showed cytotoxicity against colon (HT-29) cancer cell lines } \\
\text { at concentrations above } 125 \mu \mathrm{g} \mathrm{mL}^{-1}\end{array}$ & Miri et al., 2020 \\
\hline
\end{tabular}




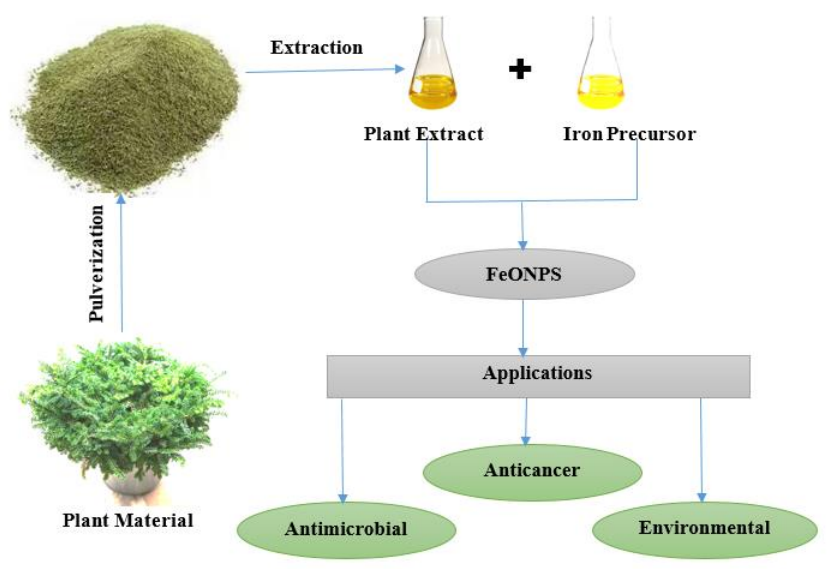

Figure 1. Green synthesis of iron oxide nanoparticles.

\subsection{Possible mechanism for the synthesis of IONPS}

Three stages, namely activation, growth and termination stage, are involved in the synthesis of IONPs from plant sources. Plant extracts serve as reducing agents for the bio-reduction of iron ion due to the chemical constituents found in plant extract. During synthesis, iron ions react with chemical constituents such as flavonoids, polyphenols and tannins via reduction and oxidation reactions. The electron rich biomolecules with $(-\mathrm{OH})$ functional groups has the efficiency of reducing the iron ions $\left(\mathrm{Fe}^{2+}\right.$ or $\left.\mathrm{Fe}^{3+}\right)$ from divalent or trivalent oxidation state depending on the iron precursor used to metallic form $\mathrm{Fe}^{0}$. This zerovalent iron will then be converted to IONPs due to some chemical reactivity. Evidently, some reporters have deduced from the functional group identification via Fourier transform infrared spectroscopy (FTIR) analysis that $\mathrm{OH}$ functional group in the extract are responsible for bio-reduction (Mohamed et al., 2020). The growth phase occurs during the annealing and segregation of iron atoms which progressively combined to yield IONPs. Finally, the termination step encompasses the stabilization of synthesized IONPs, which occurs when the equivalent amount of function groups found in the extract bind with the surface of the IONPs. Another study has reported the three stages involved in the formation mechanism of IONPs as; complexing of iron cation with hydroxyl functional group, simultaneous bio-reduction of iron cation with hydroxyl functional group to form IONPs and capping of formed IONPs with hydroxyl containing functional group (Thilagavathi et al., 2016). The flow chart illustrating the synthesis of IONPs from plant material is presented in Fig. 1.

\section{Optimization}

During the synthesis of IONPs some conditions have to be attained to obtain maximum yield and desired morphological features. Such conditions and parameters are ratios of volume of extracting solvent to plant material, temperature, concentration of precursor solution, $\mathrm{pH}$ of solution, reaction and incubation time.

\subsection{Effect of precursor}

Result from previous study had shown different precursors adopted for the green synthesis of IONPs using plant extract. Examples of such precursors are ferric nitrate, ferric chloride, iron acetate, ferrous sulphate, ferric citrate, ammonium ferric citrate. Some mixture of precursors such as mixture of ferrous sulphate and ferric chloride, mixture of potassium ferricyanide and potassium ferrocyanide. The study conducted by Rajendran and Sen (2016) on the effect of precursors on the synthesis of IONPs showed that there was a huge variation in number of days taken for the synthesis of IONPs using different precursors. They stated that the solubility of precursors in water has influence on the reaction kinetics. Furthermore, they concluded that all the precursors showed different morphological features when the IONPs synthesized were compared. Another study had revealed that the nature of the precursor used for the green synthesis of IONPs determine its reaction time, shape and size (Sayed and Polshettiwar, 2015).

\subsection{Effect of concentration of precursor}

Studies have shown that concentration of precursor influence the time taken for the synthesis of IONPs. Increase in concentration of precursor causes an increase in the rate of synthesis while decrease in concentration of precursor has been linked with delay in bio-reduction process during IONPs. This phenomenon was attributed to inadequate proportion of biomolecules present in the extract to the precursor for growth and nucleation of nanocrystals in the solution (Zhu et al., 2012). The influence of concentration of precursor on particle size has been reported, decrease in concentration of precursor have been found to yield IONPs with decrease particle size and vice versa (Verma and Mehata, 2016). Nucleation and growth models of NPs have been adopted in the explanation of the effect of concentration of precursor on particle size claiming that the number of NPs formed in the solution 
increased with increase in precursor concentration. Aside nucleation rate, delay in particle growth was also noted as the concentration of precursor increases resulting to increase in the availability of elemental concentrations of precursor which cause increase in the size of particle (Cho et al., 2016).

\subsection{Effect of pH}

The $\mathrm{pH}$ which determines the level of acidity and basicity of reaction medium has been detected to be an important factor that influences the synthesis of IONPs and other metal oxide NPs from plants materials. The influences of $\mathrm{pH}$ of solution medium on size and texture of NPs synthesized from plant extract has been documented (Jacob et al., 2019). Therefore, variation of the $\mathrm{pH}$ of solution has been adopted in regulation and control of shape and size of the synthesized NPs (Huang et al., 2015). The $\mathrm{pH}$ of basic medium (7 to 9) has been reported as the optimum condition for the synthesis of IONPs Aeromonas hydrophila (Lenders et al., 2016). The biosynthesis that occurs at pH 12 and 4 has been reported to completely retard the synthesis of IONPs. This indicated that extreme acidic and basic conditions do not favor the synthesis of IONPs using plant extract (Woźnica et al., 2003).

\subsection{Effect of temperature}

Temperature is one of the crucial parameters that influences the physical, chemical and biological method of synthesizing IONPs. The temperature requirement for the green synthesis of IONPs using plant extract is in the range of 25 to $100{ }^{\circ} \mathrm{C}$ (Patra et al., 2014). However, most researchers prefer the synthesis of IONPs at room temperature due to the volatility of some secondary metabolites of plants extract that are needed for bio-reduction of iron ions. Findings have shown that temperature of the reaction solution influences the morphological identity of NPs (Patra et al., 2014). Findings from the UV-visible analysis of IONPs synthesis from plant part at temperatures interval of 40 and $30^{\circ} \mathrm{C}$ shown complete synthesis at 48 and $72 \mathrm{~h}$, respectively. This indicated that rapid synthesis occurs at higher temperatures. This report also indicated that an increase in temperature beyond $40{ }^{\circ} \mathrm{C}$ led to poor synthesis of IONPs, which was attributed to the inactivation of biomolecules liable for the reduction of the iron precursor (Rajendran and Sen, 2016). However, a report has shown the successful synthesis of IONPs using Punica granatum seed extract at temperature of $70{ }^{\circ} \mathrm{C}$ (Bibi et al., 2019).

\subsection{Time or reaction and incubation}

The influence of incubation time on NPs synthesized using plant extract have been examined to influence the morphological properties and qualities of NPs (Harlekar et al., 2014). Other factors, such as storage conditions, device used for storage and exposure to light also affect the reaction time of IONPs. Long time incubation period has been documented to cause aggregation and shrinkage of particles (Saif et al., 2016).

\subsection{Effect of type of plant extracts and concentrations of on IONPs synthesis}

The synthesis of IONPs using plants extract is dependent on types of phytochemical found in the extract and the volume used (Devatha et al., 2018). The volume of plant extract used for the synthesis of NPs influence its duration of complete synthesis. When large volume of extract is being used, the rate of synthesis occurs rapidly because more chemical constituents are available in the solution which bind with the iron precursor to effect rapid bio-reduction and stabilization of IONPs while limited volume of extracts are being used the rate of IONPs formation decreases because there are insufficient biomolecules to bind with the metal precursor, which finally result into instability of NPs formed because the iron precursor would not be completely reduced to zerovalent form (Fazlzadeh et al., 2017). To attain an optimum condition for the green synthesis of IONPs, the ratio of the volume of plant extract must correspond to the concentration of iron precursor used because complete bio-reduction occur when there is equivalent amount of iron precursor and functional groups capable of causing reduction (Toledo et al., 2018). Also, the nature and kind of phytochemical available in plant extract influences the yield of IONPs produced (Gholami et al., 2018). The yield of IONPs depend largely on the volume of extract used for synthesis. High volume of extract has been reported induced to increased yield of synthesized IONPs when various volumes of plant extract were used, this was linked to the present of more functional groups, which react with the iron salt to produce improved absorption (Sumera et al., 2018). Findings have proved that volume and kind of extract used for NPs synthesis also affected their morphological properties and biological activities (Shen et al., 2017). 


\section{Characterization techniques}

Several techniques have been used for the evaluation of the properties of synthesized IONPs. The confirmation of IONPs formation is examined with UV spectroscopy (Ramesh et al., 2018). Fourier transform infrared spectroscopy (FTIR) is used for the functional group identification (Devi et al., 2018). The morphological properties are determined by microscopy techniques such as transmission electron microscope (TEM), scanning electron microscopy (SEM), and atomic force microscopy (AFM) (Lassoued et al., 2017). The crystallinity of synthesized IONPs is determined with X-ray diffraction (Akintelu et al., 2020a) while the purity and composition of element are measured with EDX (Rufus et al., 2017) and total reflection X-ray fluorescence (TXRF) (Kulesh et al., 2016).

\subsection{Nanoparticle formation analysis}

Ultraviolet visible spectroscopy is a technique used for the confirmation of the formation of metal NPs and metal oxide NPs, such as IONPs (Madubuonu et al., 2020). This is carried out by the measurement of its surface plasmon resonance and estimation of the oscillations of conduction band electrons obtained in the electromagnetic radiation (Madubuonu et al., 2020). Ultraviolet analysis has been used to study the stability, size, aggregation and structure of the NPs (Aisida et al., 2020a). Each metal oxide and metal NPs have specific absorbance wavelength and this is obtained from the UV spectrum when incident rays of light encounter the conduction band electrons on the surface of the metal NPs (Akintelu et al., 2020b). The specific absorbance band for IONPs is in the range of 280 to $450 \mathrm{~nm}$ on the UV spectrum (Aisida et al., 2020b). Findings obtained from recent studies on the use of UV analysis for the confirmation of IONPs formation are summarized in Tab. 1.

\subsection{Functional group identification}

Fourier transform infrared spectroscopy is useful for the identification of the functional groups present in the plant extract and IONPs (Kumar et al., 2016). It is equally used in the determination of the functional groups that participated in the bio-reduction of the iron precursors (Mirza et al., 2018). Fourier transform infrared spectroscopy analysis can produce the absorption and infrared emission spectrum of solid, liquid and gas. The uniqueness in the combination of atoms of biomolecules enhance the identification of functional groups present in synthesized IONPs using the spectra obtained from FTIR analysis (Vasantharaj et al., 2019). The spectrum obtained from FTIR spectroscopic analysis presents fingerprint containing the absorption peaks that correspond to the wavelength of vibrations within the bounds of atoms of the NPs (Ibraheem et al., 2019; Sneha and Karthikeyan, 2019). Fourier transform infrared spectroscopy analysis have been used by numerous researchers to confirm the presence of some biomolecules, such as flavonoids, tannins, alkaloids, saponins in the extract of plants used for the bio-reduction of iron precursors during the formation of IONPs (Rahmani et al., 2019). The prominent functional groups that are responsible for the reduction process during the synthesis of IONPs obtained from previous studies are presented in Tab. 1.

\subsection{Morphological assessment of IONPs}

\subsubsection{Transmission electron microscope (TEM)}

Transmission electron microscope is one of the frequently used characterization tools for shape, size, and morphology determination of IONPs (Ebrahiminezhad et al., 2017a). Conversely, the IONPs preparatory procedure for TEM analysis is very complicated because the sample (IONPs) must be very thin for electron transmittance. The IONPs are enclosed in thin films prepared on copper grids coated with carbon by releasing small quantity of IONPs in solution onto the grid and extra solution on the grid are removed with blotting papers (Rizwan et al., 2018). To aid easy penetration of monochromatic beam of electrons through the sample which produce an image on the viewing screen, the prepared samples are dried under a mercury lamp (Liu et al., 2015). The used of TEM in the morphological assessment of IONPs synthesized from several plant materials have been reported by many researches and summary of their results are documented in Tab. 1.

\subsubsection{Scanning electron microscopy (SEM)}

Scanning electron microscopy is an electron microscopy-based technique that have been used for the morphological evaluation of numerous NPs via direct visualization (Akintelu et al., 2021). These techniques have some unique benefits for morphological and size analysis when compared with other available techniques. For the preparatory procedures of IONPs for SEM analysis. The IONPs 
solution will be evaporated to dryness, the powder obtained are then mounted on a sample holder of the SEM machine and will be coated with a conductive metal using a sputter coater (Ebrahiminezhad et al., 2017b). Subsequently, a beam of high energy electrons will be focused to the IONPs to produce several signals on its surface (Ranmadugala et al., 2017). Then the signals on the IONPs surface are captured by electron beams and are recorded by the detector where information about the crystalline structure, external morphology, orientation and chemical composition of IONPs are determined (Sulaiman et al., 2018). The deficiency of SEM is in its inability to provide only accurate and sufficient information about the average size distribution of IONPs (Rajiv et al., 2017). Findings on the morphological determination of synthesized IONPs using several plant extracts via TEM analysis are summarized in Tab. 1.

\subsubsection{Atomic force microscopy (AFM)}

Several findings have shown the use of AFM in morphological evaluation of NPs (Adio et al., 2017). This technique is based on scanning of samples (IONPs) using a probe tip at the submicron level and with the aid of installed software-based image processing crucial information about morphology, surface texture, length, width, and height of NPs can be deduced (Jubb and Allen, 2010). For sample preparation for AFM analysis, a small amount of IONPs solution is placed on a glass slipcover attached to the AFM stub and dried over nitrogen gas at ambient temperature. Several images are recorded for better interpretation (Jagathesan and Rajiv, 2018). This instrument makes the use of the forces between the surface and the tip of the sample in generating topographical map which is scanned in contact mode (Bishnoi et al., 2018). The advantages of AFM in morphological evaluation of NPs does not require sample pretreatment before producing their images, it can be used to evaluate the morphological features of nonconducting samples and it also produce information about the volume and height of NPs (Katata-Seru et al., 2018).

\subsubsection{Elemental composition}

\subsubsection{Energy dispersive $X$-ray spectra (EDX)}

In order to evaluate the purity and elemental composition of NPs synthesized using plant extracts, some researchers have used EDX technique (Yadav and Fulekar, 2018). The elemental composition of IONPs is determined from the X-rays emission obtained from IONPs after they have been bombarded with an electron beam (Khalil et al., 2017). Also, the use of an attached EDS detector to SEM have been used to determine the composition of elements in IONPs by estimating the number of X-rays emitted to balance the difference in energy of the two electrons (Badni et al., 2016). This is attainable because the emitted X-ray energy is a characteristic identity of the element when quantitatively and qualitatively analyzed (Akintelu et al., 2020c).

\subsubsection{Crystallinity evaluation}

XRD have been reported as a good technique for the crystallinity assessment of synthesized NPs (Demirezen et al., 2018). The crystallinity assessment is accomplished by analyzing the lattice and structure parameters of the diffracted IONPs powder by measuring the diffraction angle when X-ray beam incident on them. With the aid of Scherrer formula represented with Eq. 2 the crystal size can be determined based on the X-ray peaks width (Truskewycz et al., 2016).

Crystal size $=\frac{\mathrm{k} \lambda}{\beta \cos \theta}$

where $\mathrm{k}=$ shape factor $(0.94), \lambda=$ wavelength of incident $\mathrm{X}$-ray, $\beta=$ full width half maximum and $\theta=$ Bragg's angle.

\section{Applications of IONPs synthesized from plant extract}

\subsection{Antimicrobial applications}

Various investigations have been carried out to enhance the antimicrobial activities of available antibiotic drugs and also to develop novel antimicrobial agents to reduce/eliminate the microbial resistance towards readily available antibiotics and antiseptic (Ansari et al., 2017). Reports from the in vitro antimicrobial studies of metal and metal oxide NPs on numerous microbial species showed that metal oxide and metal NPs demonstrated remarkable inhibition against the growth of tested microbial species when compared with commercially available antibiotics and antiseptic (Rana et al., 2019). However, the antimicrobial activities of IONPs and other NPs depends upon majorly on particle size and material used for synthesis. Over the past decades, IONPs functionalized with therapeutic agents, such as 
antimicrobials, have gained scientific and industrial attention because of their impressive results of antimicrobial and antibiofilm activities (Holban, 2015). When IONPs agglomerate, their surfaces are modified with important biological molecules and other polymer, IONPs have been coated with several antimicrobial agents to prevent IONPS agglomeration in attempt to extend the utility of engineered IONPs in biomedical applications (Seabra et al., 2017). The utilization of metal NPs have been recommended as the most promising approach for eradicating microbial drug resistance because of their multiple reaction mechanisms with microbial cells (Seabra et al., 2017). Some of the reaction mechanisms are generation of pits in the bacterial cell, which causes fragmentation of the cell wall, denaturation of the outermost membrane of microbes especially bacterial, and reaction with the disulfide groups of enzymes to obstruct metabolic processes, which causes cell death (Rai et al., 2013). Like other metal and metal oxide NPs such as silver, gold, zinc oxide and copper oxide. The IONPs also possess potential antimicrobial activities (Taghizadeh et al., 2019). Patra et al. (2017) reported that IONPs synthesized using corn plant extract exerted synergistic antibacterial activities against tested bacterial species. Previous study on the bactericidal action of IONPs synthesized using the fruit extract of Couroupita guianensis revealed that particles exhibited effective bactericidal potency on tested human pathogens (Gao et al., 2017). Findings have equally shown that the growth of Proteus mirabilis and Escherichia coli can be limited by IONPS obtained using leaf extract of Argemone mexicana L. (Arokiyaraj et al., 2013). The potential of IONPs in combating both gram positive and gram-negative bacteria have been reported effective and further strategies to develop synergistic IONPs platform which could function as carrier system for the treatment of microbial infection in future have been devised (Nehra et al., 2018). Some results obtained from recent studies on the antimicrobial potency of IONPs synthesized using plant extracts against the growth of some deadly human pathogens are shown in Tab. 2.

\subsection{Anticancer applications}

Lack of selective targets and multidrug resistance have made the effective treatment of tumor and cancer an abortive and worrisome issue (El-Boubbou, 2018). The advancement in nanotechnology and nanoscience over the years have shown some effective contribution of NPs in cancer treatment due to their exceptional features and mechanism of reaction with cancerous cells (Sathishkumar et al., 2018). Among the existing metal oxide NPs, IONPs have been recommended as good anticancer therapy due to their large surface area to graft targeting substrates and moieties, great resistance to in vivo degradation and potential synergistic activity in influencing the sensitivity of drugs towards the treatment of cancer (Bahrami et al., 2017). The cytotoxicity effect of biosynthesized IONPs against human HepG2 liver cell lines reveal that IONPs is capable of inhibiting the growth of cancer cell as the concentrations of IONPs increases (Rajendran et al., 2015). It was deduced from an investigation conducted to determine the cytotoxicity efficiency of lead oxide NPs and IONPs against HepG2 cells that IONPs exhibited higher cytotoxicity efficiency of $38.49 \%$ against HepG2 cells while the cytotoxicity efficiency of lead oxide NPs was $20.88 \%$. The difference in the efficiency of the metal oxides in inhibiting the growth of HepG2 cells was linked with the smaller particle size of IONPs (Muhammad et al., 2019). The result obtained from the in vitro cytotoxicity evaluation of various concentrations of IONPs synthesized using flaxseed against MCF-7 cells revealed high toxicity efficacy at concentrations of $4.7 \mu \mathrm{g} \mathrm{mL}^{-1}$ and above (Rahmani et al., 2020). The high cytotoxicity efficiency of IONPs against the MCF-7 cell line was attributed to the ability of IONPs in causing breakdown of MCF-7 cells membrane by interacting with the phospholipid molecules in the cell layer (Berry et al., 2004). An outstanding cytotoxicity effect has been documented from the action of Psoralea corylifolia mediated IONPs against significant anticancer activity against renal tumor cells (Nagajyothi et al., 2017).

\subsection{Environmental application}

The wide use of anionic and cationic dyes in textiles, plastic, pharmaceuticals, leather, printing, and paper milling industries had led to their gigantic demand and supply across the globe (Fowsiya et al., 2016). Findings have shown that after manufacturing processes in the aforementioned industries over $20 \%$ of the total dyes used are wasted and are discharged into the environment where they resulted into various forms of environmental pollution (Ratna and Padhi, 2012). The discharge of dye and other toxic waste into the ecosystem have result to the death of many aquatic animals, water turbidity and several human health menace (Jin et al., 2018). However, the management and effective control of effluents containing dyes have been a daunting challenge. The implication of the environmental challenges associated with industrial effluents have led to the investigation of the catalytic 
degradation and oxidation of dyes by metal and metal oxide NPs (Thandapani et al., 2018). Interestingly, metal oxides, such as zinc, copper, titanium and iron oxides, have showed good dye degradation efficiency (Gonawala and Mehta, 2014; Stan et al., 2015). The photodegradation of dyes by IONPs have been attributed to the easy adsorption of dyes linked with the high surface area to mass ratio and large number of surface reactive sites of metal oxide NPs (Dutta et al., 2014). Catalyst loading, pH, temperature, and time have reported as the major factors affecting the photocatalytic activities of IONPs (Ahmed et al., 2020). Several results obtained from the applications of IONPs on environmental control of toxic effluent containing dyes and inorganic substance are documented in Tab. 2.

\section{Conclusion}

This review discussed elaborately the various methods and techniques involved in the synthesis and characterization of IONPs. In general, the bioactive constituents of plant extract used for the synthesis of IONPs offer other benefits, such as improved biological activities and prevention of agglomeration aside been a reducing and stabilizing agent during the process of synthesis. The optimum conditions for the proper synthesis and improved yield of IONPs with desirable properties are well discussed. Review from the literature shows that plant-based synthesis is environmentally friendly, scalable to industrial production, nontoxic, very fast and consume less energy. Despite the numerous applications of biosynthesized IONPs in effluent treatment, catalysis and biomedicine, there is need for advance study to puffer solution to the challenges in comprehending the subsurface mechanistic pathways and transport of IONPs in the environments and their toxicological consequences.

\section{Authors' contribution}

Conceptualization: Akintelu, S. A.

Data curation: Oyebamiji, A. K.

Formal Analysis: Oyebamiji, A. K.; Folorunso, A. S.

Funding acquisition: Not applicable.

Investigation: Akintelu, S. A.; Folorunso, A. S.; Oyebamiji, A. K.

Methodology: Folorunso, A. S.

Project administration: Oyebamiji, A. K.

Resources: Not applicable

Software: Not applicable.
Supervision: Oyebamiji, A. K.

Validation: Olugbeko, S. C.

Visualization: Akintelu, S. A.

Writing - original draft: Akintelu, S. A.

Writing - review \& editing: Olugbeko, S. C.

\section{Data availability statement}

The data will be available upon request

\section{Funding}

Not applicable

\section{Acknowledgments}

We are grateful to Chinese Government council, School of Chemistry and Chemical Engineering, Beijing Institute of Technology, Beijing, China and Department of Pure and Applied Chemistry, Ladoke Akintola University of Technology for their assistance in the course of this study.

\section{References}

Adio, S. O.; Omar, M. H.; Asif, M.; Saleh, T. A. Arsenic and selenium removal from water using biosynthesized nanoscale zero-valent iron: A factorial design analysis. Process Saf. Environ. Prot. 2017, 107, 518-527. https://doi.org/10.1016/j.psep.2017.03.004

Ahmad, W.; Khan, A. U.; Shams, S.; Qin, L.; Yuan, Q.; Ahmad, A.; Wei, Y.; Khan, Z. U. H.; Ullah, S.; Rahman, A. U. Eco-benign approach to synthesize spherical iron oxide nanoparticles: A new insight in photocatalytic and biomedical applications. J. Photochem. Photobiol. B, Biol. 2020, 205, 111821. https://doi.org/10.1016/j.jphotobiol.2020.111821

Ahmed, A.; Usman, M.; Yu, B.; Ding, X.; Peng, Q.; Shen, Y.; Cong, H. Efficient photocatalytic degradation of toxic Alizarin yellow $\mathrm{R}$ dye from industrial wastewater using biosynthesized Fe nanoparticle and study of factors affecting the degradation rate. J. Photochem. Photobiol. B, Biol. 2020, 202 ,

111682 .

https://doi.org/10.1016/j.jphotobiol.2019.111682

Aisida, S. O.; Madubuonu, N.; Alnasir, M. H.; Ahmad, I.; Botha, S.; Maaza, M.; Ezema, F. I. Biogenic synthesis of iron oxide nanorods using Moringa oleifera leaf extract for antibacterial applications. Appl. Nanosci. 2020a, 10, 305315. https://doi.org/10.1007/s13204-019-01099-x

Aisida, S. O.; Ahmad, I.; Ezema, F. I. Effect of calcination on the microstructural and magnetic properties of PVA, PVP and PEG assisted zinc ferrite nanoparticles. Phys. B: 
Condens. Matter 2020b, 579, 411907. https://doi.org/10.1016/j.physb.2019.411907

Aisida, S. O.; Ugwu, K.; Akpa P.; Nwanya, A. C.; Nwankwo, U.; Bashir, A. K. H.; Madiba, I.; Ahmed, I.; Ezema, F. Synthesis and characterization of iron oxide nanoparticles capped with Moringa oleifera: The mechanisms of formation effects on the optical, structural, magnetic and morphological properties. Mater. Today: Proc. 2021, 36, 214-218.

Akintelu, S. A.; Folorunso, A. S. Biosynthesis, Characterization and Antifungal Investigation of $\mathrm{Ag}-\mathrm{Cu}$ Nanoparticles from Bark Extracts of Garcina kola. Stem Cell 2019a, $10 \quad$ (4), 30-37. https://doi.org/10.7537/marsscj100419.05

Akintelu, S. A.; Folorunso, A. S. Characterization and Antimicrobial Investigation of Synthesized Silver Nanoparticles from Annona muricata Leaf Extracts. Journal of Nanotechnology Nanomedicine \& Nanobiotechnology 2019b, 6, 022. https://doi.org/10.24966/NTMB-2044/100022

Akintelu, S. A.; Folorunso, A. S.; Ademosun, O. T. Instrumental Characterization and Antibacterial Investigation of Silver Nanoparticles Synthesized from Garcinia Kola Leaf. Journal of Drug Delivery and Therapeutics 2019a, 9 (6-S), 58-64. https://doi.org/10.22270/jddt.v9i6-s.3749

Akintelu, S. A.; Folorunso, A. S.; Oyebamiji, A. K.; Erazua, E. A. Antibacterial potency of silver nanoparticles synthesized using Boerhaavia diffusa leaf extract as reductive and stabilizing agent. Int. J. Pharm. Sci. Res. 2019b, 10 (12), 374-380.

Akintelu, S. A.; Olugbeko, S. C.; Folorunso, A. S. A review on synthesis, optimization, characterization and antibacterial application of gold nanoparticles synthesized from plants. Int. Nano Lett. 2020a, 10, 237-248. https://doi.org/10.1007/s40089-020-00317-7

Akintelu, S. A.; Olugbeko, S. C.; Folorunso, F. A.; Oyebamiji, A. K.; Folorunso, A. S. Characterization and Pharmacological Efficacy of Silver Nanoparticles Biosynthesized Using the Bark Extract of Garcinia Kola. J. Chem. 2020b, 2020, 2876019. https://doi.org/10.1155/2020/2876019

Akintelu, S. A.; Bo, Y.; Folorunso, A. S. A Review on Synthesis, Optimization, Mechanism, Characterization, and Antibacterial Application of Silver Nanoparticles Synthesized from Plants. J. Chem. 2020c, 2020, 3189043. https://doi.org/10.1155/2020/3189043

Akintelu, S. A.; Yao, B.; Folorunso, A. S. Green Synthesis, Characterization, and Antibacterial Investigation of Synthesized Gold Nanoparticles (AuNPs) from Garcinia kola Pulp Extract. Plasmonics 2021, 16, 157-165. https://doi.org/10.1007/s11468-020-01274-9

Alam, T.; Khan, R. A. A.; Ali, K.; Ali, A.; Sher, H.; Ullah, Z.; Ali, M. Biogenic synthesis of iron oxide nanoparticles via Skimmia laureola and their antibacterial efficacy against bacterial wilt pathogen Ralstonia solanacearum. Mater. Sci. $\begin{array}{llll}\text { Eng. } & C & \text { 2019, } & \text { 98, }\end{array}$ https://doi.org/10.1016/j.msec.2018.12.117

Alharbi, K. K.; Al-sheikh, Y. A. Role and implications of nanodiagnostics in the changing trends of clinical diagnosis. Saudi J. Biol. Sci. 2014, 21 (2), 109-117. https://doi.org/10.1016/j.sjbs.2013.11.001

Ali, A.; Zafar, H.; Zia, M.; ul Haq, I.; Phull, A. R.; Ali, J. S.; Hussain, A. Synthesis, characterization, applications, and challenges of iron oxide nanoparticles. Nanotechnol. Sci. Appl. 2016, 9, 49-67. https://doi.org/10.2147/NSA.S99986

Ansari, S. A.; Oves, M.; Satar, R.; Khan, A.; Ahmad, S. I.; Jafri, M. A.; Zaidi, S. K.; Alqahtani, M. H. Antibacterial activity of iron oxide nanoparticles synthesized by coprecipitation technology against Bacillus cereus and Klebsiella pneumoniae. Pol. J. Chem. Tech. 2017, 19 (4), 110-115. https://doi.org/10.1515/pjct-2017-0076

Arokiyaraj, S.; Saravanan, M.; Prakash, N. K. U.; Arasu, M. V.; Vijayakumar, B.; Vincent, S. Enhanced antibacterial activity of iron oxide magnetic nanoparticles treated with Argemone Mexicana L. leaf extract: An in vitro study. Mater. Res. Bull. 2013, 48, 3323-3327. https://doi.org/10.1016/j.materresbull.2013.05.059

Arsalani, S.; Guidelli, E. J.; Silveira, M. A.; Salmon, C. E. G.; Araujo, J. F. D. F.; Bruno, A. C.; Baffa, O. Magnetic $\mathrm{Fe}_{3} \mathrm{O}_{4}$ nanoparticles coated by natural rubber latex as MRI contrast agent. J. Magn. Magn. Mater. 2019, 475, 458-464. https://doi.org/10.1016/j.jmmm.2018.11.132

Arularasu, M. V.; Devakumar, J.; Rajendran, T. V. An innovative approach for green synthesis of iron oxide nanoparticles: Characterization and its photocatalytic activity. Polyhedron 2018, 156, 279-290. https://doi.org/10.1016/j.poly.2018.09.036

Asghar, M. A.; Zahir, E.; Shahid, S. M.; Khan, M. N.; Asghar, M. A.; Iqbal, J.; Walker, G. Iron, copper and silver nanoparticles: Green synthesis using green and black tea leaves extracts and evaluation of antibacterial, antifungal and aflatoxin $\mathrm{B}_{1}$ adsorption activity. LWT 2018, 90, 98-107. https://doi.org/10.1016/j.lwt.2017.12.009

Assa, F.; Jafarizadeh-Malmiri, H.; Ajamein, H.; Anarjan, N.; Vaghari, H.; Sayyar, Z.; Berenjian, A. A biotechnological perspective on the application of iron oxide nanoparticles. Nano Research 2016, 9, 2203-2225. https://doi.org/10.1007/s12274-016-1131-9 
Badni, N.; Benheraoua, F. Z.; Tadjer, B.; Boudjemaa, A.; El Hameur, H.; Bachari, K. Green synthesis of $\alpha-\mathrm{Fe}_{2} \mathrm{O}_{3}$ nanoparticles using Roman nettle. Proceedings of the Third International Conference on Energy, Materials, Applied Energetics and Pollution, ICEMAEP2016, Constantina, Algeria, October 30-31, 2016; Kadja, M., Zaatri, A., Nemouchi, Z., Bessaih, R., Benissaad, S., Talbi, K., Eds.

Bahrami, B.; Hojjat-Farsangi, M.; Mohammadi, H.; Anvari, E.; Ghalamfarsa, G.; Yousefi, M.; Jadidi-Niaragh, F. Nanoparticles and targeted drug delivery in cancer therapy. Immunol. Lett. 2017, 190, 64-83. https://doi.org/10.1016/j.imlet.2017.07.015

Bashir, A. K. H.; Mayedwa, N.; Kaviyarasu, K.; Razanamahandry, L. C.; Matinise, N.; Bharuth-Ram, K.; Tchokonté, M. B. T.; Ezema, F. I.; Maaza, M. Investigation of electrochemical performance of the biosynthesized $\alpha$ $\mathrm{Fe}_{2} \mathrm{O}_{3}$ nanorods. Surf. Interfaces 2019, 17, 100345. https://doi.org/10.1016/j.surfin.2019.100345

Berry, C. C.; Wells, S.; Charles, S.; Aitchison, G.; Curtis, A. S. G. Cell response to dextran-derivatised iron oxide nanoparticles post internalization. Biomaterials 2004, 25 (23), 5405-5413.

https://doi.org/10.1016/j.biomaterials.2003.12.046

Bibi, I.; Nazar, N.; Ata, S.; Sultan, M.; Ali, A.; Abbas, A.; Jilani, K.; Kamal, S.; Sarim, F. M.; Khan, M. I.; Jalal, F.; Iqbal, M. Green synthesis of iron oxide nanoparticles using pomegranate seeds extract and photocatalytic activity evaluation for the degradation of textile dye. J. Mat. Res. Technol. 2019, 8 (6), 6115-6124. https://doi.org/10.1016/j.jmrt.2019.10.006

Bishnoi, S.; Kumar, A.; Selvaraj, R. Facile synthesis of magnetic iron oxide nanoparticles using inedible Cynometra ramiflora fruit extract waste and their photocatalytic degradation of methylene blue dye. Mater. Res. Bull. 2018, 97 ,

121-127.

https://doi.org/10.1016/j.materresbull.2017.08.040

Bolade, O. P.; Akinsiku, A. A.; Adeyemi, A. O.; Williams, A. B.; Benson, N. U. Dataset on phytochemical screening, FTIR and GC-MS characterisation of Azadirachta indica and Cymbopogon citratus as reducing and stabilising agents for nanoparticles synthesis. Data Brief 2018, 20, 917-926. https://doi.org/10.1016/j.dib.2018.08.133

Bolade, O. P.; Williams, A. B.; Benson, N. U. Green synthesis of iron-based nanomaterials for environmental remediation: A revie. Environ. Nanotechnol. Monit. Manag. 2020, 13 ,

100279.

https://doi.org/10.1016/j.enmm.2019.100279

Buiyan, S. H.; Muhammed, Y. M.; Paul, S. C.; Aka, T. D.; Saha, O.; Rahaman, M.; Sharif, J. I.; Habiba, O.; Ashaduzzaman. Green synthesis of iron oxide nanoparticle using Carica papaya leaf extract: application for photocatalytic degradation of remazol yellow RR dye and antibacterial activity. Heliyon 2020, 6 (8), e04603. https://doi.org/10.1016/j.heliyon.2020.e04603

Cabrera, L.; Gutierrez, S.; Menendez, N.; Morales, M. P.; Herrasti, P. Magnetite nanoparticles: Electrochemical synthesis and characterization. Electrochim. Acta 2008, 53 (8),

https://doi.org/10.1016/j.electacta.2007.12.006

$3436-3441$

Chauhan, S.; Upadhyay, L. S. B. Biosynthesis of iron oxide nanoparticles using plant derivatives of Lawsonia inermis (Henna) and its surface modification for biomedical application. Nanotechnol. Environ. Eng. 2019, 4, 8. https://doi.org/10.1007/s41204-019-0055-5

Cheera, P.; Karlapudi, S.; Sellola, G.; Ponneri, V. A facile green synthesis of spherical $\mathrm{Fe}_{3} \mathrm{O}_{4}$ magnetic nanoparticles and their effect on degradation of methylene blue in aqueous solution. J. Mol. Liq. 2016, 221, 993-998. https://doi.org/10.1016/j.molliq.2016.06.006

Cho, J. S.; Lee, J.-C.; Rhee, S.-H. Effect of precursor concentration and spray pyrolysis temperature upon hydroxyapatite particle size and density. J. Biomed. Mater. Res. Part B Appl. Biomater. 2016, 104 (2), 422-430. https://doi.org/10.1002/jbm.b.33406

Demirezen, D. A.; Yilmaz, S.; Yilmaz, D. Green synthesis and characterization of iron nanoparticles using Aesculus hippocastanum seed extract. Int. J. Adv. Sci. Technol. 2018, 6 (2) (Suppl. 2), 25-29.

Desalegn, B.; Megharaj, M.; Chen, Z.; Naidu, R. Green synthesis of zero valent iron nanoparticle using mango peel extract and surface characterization using XPS and GC-MS. Heliyon 2019, $\quad 5 \quad$ (5), https://doi.org/10.1016/j.heliyon.2019.e01750

Devatha, C. P.; Jagadeesh, K.; Mallikarjun, P. Effect of Green synthesized iron nanoparticles by Azardirachta Indica in different proportions on antibacterial activity. Environ. Nanotechnol. Monit. Manag. 2018, 9, 85-94. https://doi.org/10.1016/j.enmm.2017.11.007

Devi, H. S., Boda, M. A., Shah, M. A., Parveen, S. Green synthesis of iron oxide nanoparticles using Platanus orientalis leaf extract for antifungal activity. Green Process. Synth. 2018, 8 (1), 38-45. https://doi.org/10.1515/gps-20170145

Dutta, A. K.; Maji, S. K.; Adhikary, B. $\gamma-\mathrm{Fe}_{2} \mathrm{O}_{3}$ nanoparticles: An easily recoverable effective photo-catalyst for the degradation of rose bengal and methylene blue dyes in the waste-water treatment plant. Mater. Res. Bull. 2014, 49 , 28-34.

https://doi.org/10.1016/j.materresbull.2013.08.024 
Ebrahiminezhad, A.; Zare-Hoseinabadi, A.; Berenjian, A.; Ghasemi, Y. Green synthesis and characterization of zerovalent iron nanoparticles using stinging nettle (Urtica dioica) leaf extract. Green Process. Synth. 2017a, 6 (5).

Ebrahiminezhad, A.; Zare, M.; Kiyanpour, S.; Berenjian, A.; Niknezhad, S. V.; Ghasemi, Y. Biosynthesis of xanthangumcoated INPs by using Xanthomonas campestris. IET Nanobiotechnol. $\quad \mathbf{2 0 1 7 b}, \quad 12 \quad$ (3), 254-258. https://doi.org/10.1049/iet-nbt.2017.0199

El Shafey, A. M. Green synthesis of metal and metal oxide nanoparticles from plant leaf extracts and their applications: A review. Gruyter Green Processing and Synthesis 2020, 9 (1), 304-339. https://doi.org/10.1515/gps-2020-0031

El-Boubbou, K. Magnetic iron oxide nanoparticles as drug carriers: clinical relevance. Nanomedicine (Lond) 2018, 13 (8), 953-971. https://doi.org/10.2217/nnm-2017-0336

Fatimah, I.; Pratiwi, E. Z.; Wicaksono, W. P. Synthesis of magnetic nanoparticles using Parkia speciosa Hassk pod extract and photocatalytic activity for Bromophenol blue degradation. Egypt. J. Aquat. Res. 2020, 46 (1), 35-40. https://doi.org/10.1016/j.ejar.2020.01.001

Fazlzadeh, M.; Rahmani, K.; Zarei, A.; Abdoallahzadeh, H.; Nasiri, F.; Khosravi, R. A novel green synthesis of zero valent iron nanoparticles (NZVI) using three plant extracts and their efficient application for removal of $\mathrm{Cr}(\mathrm{VI})$ from aqueous solutions. Adv. Powder Technol. 2017, 28 (1), 122130. https://doi.org/10.1016/j.apt.2016.09.003

Folorunso, A.; Akintelu, S.; Oyebamiji, A. K.; Ajayi, S.; Abiola, B.; Abdusalam, I.; Morakinyo, A. Biosynthesis, characterization and antimicrobial activity of gold nanoparticles from leaf extracts of Annona muricata. J. Nanostruct. Chem. 2019, 9, 111-117. https://doi.org/10.1007/s40097-019-0301-1

Fowsiya, J.; Madhumitha, G.; Al-Dhabi, N. A.; Arasu, M. V. Photocatalytic degradation of Congo red using Carissa edulis extract capped zinc oxide nanoparticles. $J$. Photochem. Photobiol. B, Biol. 2016, 162, 395-401. https://doi.org/10.1016/j.jphotobiol.2016.07.011

Franzoso, F.; Nisticò, R.; Cesano, F.; Corazzari, I.; Turci, F.; Scarano, D.; Prevot, A. B.; Magnacca, G.; Carlos, L.; Mártire, D. O. Biowaste-derived substances as a tool for obtaining magnet-sensitive materials for environmental applications in wastewater treatments. Chemical Engineering Journal 2017, 310 (Part 1), 307-316. https://doi.org/10.1016/j.cej.2016.10.120

Gan, L.; Lu, Z.; Cao, D.; Chen, Z. Effects of cetyltrimethylammonium bromide on the morphology of green synthesized $\mathrm{Fe}_{3} \mathrm{O}_{4}$ nanoparticles used to remove phosphate. Mater. Sci. Eng. C 2018, 82, 41-45. https://doi.org/10.1016/j.msec.2017.08.073
Gao, L.; Fan, K.; Yan, X. Iron oxide nanozyme: a multifunctional enzyme mimetic for biomedical applications. Theranostics 2017, 7 (13), 3207-3227. https://doi.org/10.7150/thno.19738

Gebre, S. H.; Sendeku, M. G. New frontiers in the biosynthesis of metal oxide nanoparticles and their environmental applications: an overview. SN Appl. Sci. 2019, 1, 928. https://doi.org/10.1007/s42452-019-0931-4

Gholami, L.; Oskuee, R. K.; Tafaghodi, M.; Farkhani, A. R.; Darroudi, M. Green facile synthesis of low-toxic superparamagnetic iron oxide nanoparticles (SPIONs) and their cytotoxicity effects toward Neuro2A and HUVEC cell lines. Ceram. Int. 2018, 44 (8), 9263-9268. https://doi.org/10.1016/j.ceramint.2018.02.137

Gonawala, K. H.; Mehta, M. J. Removal of color from different dye wastewater by using ferric oxide as an adsorbent. Int. J. Eng. Res. Appl. 2014, 4 (5), 102-109.

Gunarani, G. I.; Raman, A. B.; Kumar, J. D.; Natarajan, S.; Jegadeesan, G. B. Biogenic synthesis of $\mathrm{Fe}$ and $\mathrm{NiFe}$ nanoparticles using Terminalia bellirica extracts for water treatment applications. Mater. Lett. 2019, 247, 90-94. https://doi.org/10.1016/j.matlet.2019.03.104

Harlekar, M.; Barve, S.; Kumar, R. Plant-Mediated Green Synthesis of Iron Nanoparticles. J. Nanoparticles 2014, 2014, 140614. https://doi.org/10.1155/2014/140614

Harshiny, M.; Iswarya, C. N.; Matheswaran, M. Biogenic synthesis of iron nanoparticles using Amaranthus dubius leaves extract as reducing agents. Powder Technol. 2015, 286, 744-749. https://doi.org/10.1016/j.powtec.2015.09.021

Harshiny, M.; Samsudeen, N.; Kameswara, R. J.; Matheswaran, M. Biosynthesized FeO nanoparticles coated carbon anode for improving the performance of microbial fuel cell. International Journal of Hydrogen Energy 2017, 42 (42), 26488-26495. https://doi.org/10.1016/j.ijhydene.2017.07.084

Holban, A. M. Magnetite nanoshuttles for fighting Staphylococcus aureus infections: a recent review. Curr. Top. Med. Chem. 2015, 15 (16), 1589-1595. https://doi.org/10.2174/1568026615666150414152431

Huang, L.; Luo, F.; Chen, Z.; Megharaj, M.; Naidu, R. Green synthesized conditions impacting on the reactivity of Fe NPs for the degradation of malachite green. Spectrochim. Acta A Mol. Biomol. Spectrosc. 2015, 137, 154-159. https://doi.org/10.1016/j.saa.2014.08.116

Ibraheem, F.; Aziz, M. H.; Fatima, M.; Shaheen, F.; Ali, S. M.; Huang, Q. In vitro Cytotoxicity, MMP and ROS activity of green synthesized nickel oxide nanoparticles using extract of Terminalia chebula against MCF-7 cells. Mater. Lett. 
2019,

234

https://doi.org/10.1016/j.matlet.2018.09.075

Iqbal, J.; Abbassi, B. A.; Ahmad, R.; Shahbaz, A.; Zahra, S. A.; Kanwal, S.; Rabbani, A.; Mahmood, T. Biogenic synthesis of green and cost-effective iron nanoparticles and evaluation of their potential biomedical properties. J. Mol. $\begin{array}{llll}\text { Struct. } & \mathbf{2 0 2 0}, & 1199, & 126979 .\end{array}$ https://doi.org/10.1016/j.molstruc.2019.126979

Jacob, P. J.; Masarudin, M. J.; Hussein, M. Z.; Rahim, R. A. Optimization of process parameters influencing the sustainable construction of iron oxide nanoparticles by a novel tropical wetlands Streptomyces spp. J. Clean. Prod. 2019, 232 ,

193-202.

https://doi.org/10.1016/j.jclepro.2019.05.359

Jagadeesan, G.; Srimathi, K.; Srinivas, N. S.; Manishkanna, S.; Vignesh, D. Green synthesis of iron oxide nanoparticles using Terminalia bellirica and Moringa oleifera fruit and leaf extracts: Antioxidant, antibacterial and thermoacoustic properties. Biocatal. Agric. Biotechnol. 2019, 21, 101354. https://doi.org/10.1016/j.bcab.2019.101354

Jagathesan, G.; Rajiv, P. Biosynthesis and characterization of iron oxide nanoparticles using Eichhornia crassipes leaf extract and assessing their antibacterial activity. Biocatal. Agric. Biotechnol. 2018, 13, 90-94. https://doi.org/10.1016/j.bcab.2017.11.014

Jin, X.; Liu, Y.; Tan, J.; Owens, G.; Chen, Z. Removal of $\mathrm{Cr}(\mathrm{VI})$ from aqueous solutions via reduction and absorption by green synthesized iron nanoparticles. J. Clean. Prod. 2018, 176, 929-936. https://doi.org/10.1016/j.jclepro.2017.12.026

Jubb, A. M.; Allen, H. C. Vibrational spectroscopic characterization of hematite, maghemite, and magnetite thin films produced by vapor deposition. ACS Appl. Mater. Interfaces 2010, 2 (10), 2804-2812. https://doi.org/10.1021/am1004943

Kamran, U.; Bhatti, H. N.; Iqbal, M.; Jamil, S.; Zahid, M. Biogenic synthesis, characterization and investigation of photocatalytic and antimicrobial activity of manganese nanoparticles synthesized from Cinnamomum verum bark extract. J. Mol. Struct. 2019, 1179, 532-539. https://doi.org/10.1016/j.molstruc.2018.11.006

Karpagavinayagam, P.; Vedhi, C. Green synthesis of iron oxide nanoparticles using Avicennia marina flower extract. Vacuum 2019, $\quad 160, \quad 286-292$. https://doi.org/10.1016/j.vacuum.2018.11.043

Katata-Seru, L.; Moremedi, T.; Aremu, O. S.; Bahadur, I. Green synthesis of iron nanoparticles using Moringa oleifera extracts and their applications: Removal of nitrate from water and antibacterial activity against Escherichia coli. J.
Mol. Liq. 2018, 256,

296-304.

https://doi.org/10.1016/j.molliq.2017.11.093

Khalil, A. T.; Ovais, M.; Ullah, I.; Ali, M.; Shinwari, Z. K.; Maaza, M. Biosynthesis of iron oxide $\left(\mathrm{Fe}_{2} \mathrm{O}_{3}\right)$ nanoparticles via aqueous extracts of Sageretia thea (Osbeck.) and their pharmacognostic properties. Green Chem. Lett. Rev. 2017, $10 \quad$ (4), 186-201. https://doi.org/10.1080/17518253.2017.1339831

Khatami, M.; Alijani, H. Q.; Fakheri, B.; Mobasseri, Heydarpour, M.; Farahani, Z. K.; Khan, A. U. Superparamagnetic iron oxide nanoparticles (SPIONs): Greener synthesis using Stevia plant and evaluation of its antioxidant properties. J. Clean. Prod. 2019, 208, 1171-1177. https://doi.org/10.1016/j.jclepro.2018.10.182

Kheshtzar, R.; Berenjian, A., Ganji, N.; Taghizadeh, S.-M.; Maleki, M.; Taghizadeh, S.; Ghasemi, Y.; Ebrahiminezhadm A. Response surface methodology and reaction optimization to product zero-valent iron nanoparticles for organic pollutant remediation. Biocatalysis and Agricultural $\begin{array}{llll}\text { Biotechnology } & \mathbf{2 0 1 9}, & 21, & 101329 .\end{array}$ https://doi.org/10.1016/j.bcab.2019.101329

Kulesh, N. A.; Novoselova, I. P.; Safronov, A. P.; Beketov, I. V.; Samatov, O. M.; Kurlyandskaya, G. V.; Morozova, M.; Denisova, T. P. Total reflection $\mathrm{x}$-ray fluorescence spectroscopy as a tool for evaluation of iron concentration in ferrofluids and yeast samples. J. Magn. Magn. Mater. 2016, 415, 39-44. https://doi.org/10.1016/j.jmmm.2016.01.095

Kumar, B.; Smita, K.; Cumbal, L.; Debut, A.; Galeas, S.; Guerrero, V. H. Phytosynthesis and photocatalytic activity of magnetite $\left(\mathrm{Fe}_{3} \mathrm{O}_{4}\right)$ nanoparticles using the Andean blackberry leaf. Mater. Chem. Phys. 2016, 179, 310-315. https://doi.org/10.1016/j.matchemphys.2016.05.045

Lassoued, A.; Dkhil, B.; Gadri, A.; Ammar, S. Control of the shape and size of iron oxide $\left(\alpha-\mathrm{Fe}_{2} \mathrm{O}_{3}\right)$ nanoparticles synthesized through the chemical precipitation method. Results Phys. 2017, 7, 3007-3015. https://doi.org/10.1016/j.rinp.2017.07.066

Lemine, O. M.; Omri, K.; Zhang, B.; El Mir, L.; Sajieddine, M.; Alyamani, A.; Bououdina, M. Sol-gel synthesis of $8 \mathrm{~nm}$ magnetite $\left(\mathrm{Fe}_{3} \mathrm{O}_{4}\right)$ nanoparticles and their magnetic properties. Superlattices Microstruct. 2012, 52, 793-799. https://doi.org/10.1016/j.spmi.2012.07.009

Lenders, J. J. M.; Mirabello, G.; Sommerdijk, N. A. J. M. Bioinspired magnetite synthesis via solid precursor phases. Chem. Sci. 2016, 7 (9), 5624-5634, https://doi.org/10.1039/C6SC00523C

Lin, J.; Weng, X.; Dharmarajan, R.; Chen, Z. Characterization and reactivity of iron-based nanoparticles synthesized by tea extracts under various atmospheres 
Chemosphere 2017, 169, 413-417. https://doi.org/10.1016/j.chemosphere.2016.11.092

Liu, G.; Sun, W.-j.; Tang, S.-s.; Liang, S.-q.; Liu, J. Synthesis of $\alpha-\mathrm{Fe}_{2} \mathrm{O}_{3} @ \mathrm{SnO}_{2}$ core-shell nanoparticles via low-temperature molten salt reaction route. Trans. Nonferrous Met. Soc. China 2015, 25 (11), 3651-3656. https://doi.org/10.1016/S1003-6326(15)64076-6

Liu, Y.; Jin, X.; Chen, Z. The formation of iron nanoparticles by Eucalyptus leaf extract and used to remove Cr(VI). Sci. Total Environ. 2018, 627, 470-479. https://doi.org/10.1016/j.scitotenv.2018.01.241

Liu, H.; Sun, Y.; Yu, T.; Zhang, J.; Zhang, X.; Zhang, H.; Zhao, K.; Wei, J. Plant-mediated biosynthesis of iron nanoparticles-calcium alginate hydrogel membrane and its eminent performance in removal of $\mathrm{Cr}(\mathrm{VI})$. Chem. Eng. J. 2019, 378, 122120. https://doi.org/10.1016/j.cej.2019.122120

Madubuonu, N.; Aisida, S. O.; Ali, A.; Ahmad, I., Zhao, T.K.; Bothag, S.; Maaza, M., Ezema, F. I. Biosynthesis of iron oxide nanoparticles via a composite of Psidium guavajaMoringa oleifera and their antibacterial and photocatalytic study. J. Photochem. Photobiol. B, Biol. 2019, 199, 111601. https://doi.org/10.1016/j.jphotobiol.2019.111601

Madubuonu, N.; Aisida, S. O.; Ahmad, I.; Botha, S.; Zhao, T.-k.; Maaza, M.; Ezema, F. I. E. Bio-inspired iron oxide nanoparticles using Psidium guajava aqueous extract for antibacterial activity. Appl. Phys. A 2020, 126, 72. https://doi.org/10.1007/s00339-019-3249-6

Miri, A.; Khatami, M.; Sarani, M. Biosynthesis, Magnetic and Cytotoxic Studies of Hematite Nanoparticles. J. Inorg. Organomet. Polym. 2020, 30, 767-774. https://doi.org/10.1007/s10904-019-01245-6

Mirza, A. U.; Kareem, A.; Nami, S. A. A.; Khan, M. S.; Rehman, S.; Bhat, S. A.; Mohammad, A.; Nishat, N. Biogenic synthesis of iron oxide nanoparticles using Agrewia optiva and Prunus persica phyto species: Characterization, antibacterial and antioxidant activity. $J$. Photochem. Photobiol. B, Biol. 2018, 185, 262-274. https://doi.org/10.1016/j.jphotobiol.2018.06.009

Mohamed, F.; Rabia, M.; Shaban, M. Synthesis and characterization of biogenic iron oxides of different nanomorphologies from pomegranate peels for efficient solar hydrogen production. J. Mater. Res. Technol. 2020, 9 (3), 4255-4271. https://doi.org/10.1016/j.jmrt.2020.02.052

Mohanraj, S.; Kodhaiyolii, S.; Rengasamy, M.; Pugalenthi, V. Green Synthesized Iron Oxide Nanoparticles Effect on Fermentative Hydrogen Production by Clostridium acetobutylicum. Appl. Biochem. Biotechnol. 2014, 173, 318331. https://doi.org/10.1007/s12010-014-0843-0
Muhammad, W.; Khan, M. A.; Nazir, M.; Siddiquah, A.; Mushtaq, S.; Hashmi, S. S.; Abbasi, B. H. Papaver somniferum $\mathrm{L}$. mediated novel bioinspired lead oxide $(\mathrm{PbO})$ and iron oxide $\left(\mathrm{Fe}_{2} \mathrm{O}_{3}\right)$ nanoparticles: In-vitro biological applications, biocompatibility and their potential towards HepG2 cell line. Mater. Sci. Eng. C 2019, 103, 109740. https://doi.org/10.1016/j.msec.2019.109740

Mukherjee, P. Stenotrophomonas and Microbacterium: Mediated Biogenesis of Copper, Silver and Iron Nanoparticles-Proteomic Insights and Antibacterial Properties Versus Biofilm Formation. J. Clust. Sci. 2017, 28, 331-358. https://doi.org/10.1007/s10876-016-1097-5

Muthukumar, H.; Matheswaran, M. Amaranthus spinosus leaf extract mediated $\mathrm{FeO}$ nanoparticles: Physicochemical traits, photocatalytic and antioxidant activity. ACS Sustainable Chem. Eng. 2015, 3 (12), 3149-3156. https://doi.org/10.1021/acssuschemeng.5b00722

Nagajyothi, P. C.; Pandurangan, M.; Kim, D. H.; Sreekanth, T.; Shim, J. Green synthesis of iron oxide nanoparticles and their catalytic and in vitro anticancer activities. J. Clust. Sci. 2017, 28, 245-257. https://doi.org/10.1007/s10876-016$1082-\mathrm{z}$

Nehra, P.; Chauhan, R. P.; Garg, N.; Verma, K. Antibacterial and antifungal activity of chitosan coated iron oxide nanoparticles. Br. J. Biomed. Sci. 2018, 75 (1), 13-18. https://doi.org/10.1080/09674845.2017.1347362

Nisticò, R. Magnetic materials and water treatments for a sustainable future. Res. Chem. Intermed. 2017, 43, 69116949. https://doi.org/10.1007/s11164-017-3029-x

Nisticò, R.; Tabasso, S.; Magnacca, G.; Jordan, T.; Shalom, M.; Fechler, N. Reactive hypersaline route: One-pot synthesis of porous photoreactive nanocomposites. Langmuir 2017a, 33 (21), 5213-5222. https://doi.org/10.1021/acs.langmuir.7b00142

Nisticò, R.; Scalarone, D.; Magnacca, G. Sol-gel chemistry, templating and spin-coating deposition: A combined approach to control in a simple way the porosity of in organic thin films/coatings. Microporous Mesoporous Mater. $\quad 2017 b, \quad 248, \quad 18-29$. https://doi.org/10.1016/j.micromeso.2017.04.017

Nisticò, R. Block copolymers for designing nanostructured porous coatings. Beilstein J. Nanotechnol. 2018, 9, 23322344. https://doi.org/10.3762/bjnano.9.218

Nisticò, R. A synthetic guide toward the tailored production of magnetic iron oxide nanoparticles. Bol. Soc. Esp. Cerám. $\begin{array}{llll}V i d r . & 2021, & 60 & \text { (1), }\end{array}$ https://doi.org/10.1016/j.bsecv.2020.01.011

Palma, D.; Prevot, A. B.; Brigante, M.; Fabbri, D.; Magnacca, G.; Richard, C.; Mailhot, G.; Nisticò, R. New 
insights on the photodegradation of caffeine in the presence of bio-based substances-magnetic iron oxide hybrid nanomaterials. Materials 2018, $11 \quad$ (7), 1084. https://doi.org/10.3390/ma11071084

Pang, Y. L.; Lim, S.; Ong, H. C.; Chong, W. T. Research progress on iron oxide-based magnetic materials: Synthesis technique sand photocatalytic applications. Ceram. Int. 2016, $42 \quad$ (1) (Part A), 9-34. https://doi.org/10.1016/j.ceramint.2015.08.144

Park, T. J.; Lee, K. G.; Lee, S. Y. Advances in microbial biosynthesis of metal nanoparticles. Appl. Microbiol. Biotechnol. 2016, 100, 521-534. https://doi.org/10.1007/s00253-015-6904-7

Pascu, O.; Carenza, E.; Gich, M.; Estradé, S.; Peiró, F.; Herranz, G.; Roig, A. Surface reactivity of iron oxide nanoparticles by microwave-assisted synthesis; comparison with the thermal decomposition route. J. Phys. Chem. C 2012, 116 (28), 15108-15116. https://doi.org/10.1021/jp303204d

Patra, J. K.; Baek, K.-H. Green Nanobiotechnology: Factors Affecting Synthesis and Characterization Techniques. J. Nanomater. $\quad \mathbf{2 0 1 4}, \quad 2014, \quad 417305$. https://doi.org/10.1155/2014/417305

Patra, J. K.; Ali, S.; Oh, I.-G.; Baek, K.-H. Proteasome inhibitory, antioxidant, and synergistic antibacterial and anticandidal activity of green biosynthesized magnetic $\mathrm{Fe}_{3} \mathrm{O}_{4}$ nanoparticles using the aqueous extract of corn (Zea mays L.) ear leaves. Artif. Cells Nanomed. Biotechnol. 2017, 45 (2),

349-356.

https://doi.org/10.3109/21691401.2016.1153484

Patra, J. K.; Baek, K.-H. Green biosynthesis of magnetic iron oxide $\left(\mathrm{Fe}_{3} \mathrm{O}_{4}\right)$ nanoparticles using the aqueous extracts of food processing wastes under photo-catalyzed condition and investigation of their antimicrobial and antioxidant activity. J. Photochem. Photobiol. B, Biol. 2017, 173, 291-300. https://doi.org/10.1016/j.jphotobiol.2017.05.045

Pinkas, J.; Reichlova, V.; Zboril, R.; Moravec, Z., Bezdicka, P.; Matejkova, J. Sonochemical synthesis of amorphous nanoscopic iron(III) oxide from $\mathrm{Fe}(\mathrm{acac})_{3}$. Ultrason. Sonochem. $\quad \mathbf{2 0 0 8}, \quad 15 \quad$ (3), 257-264. https://doi.org/10.1016/j.ultsonch.2007.03.009

Poka, L. P., Krishna, M. G., Venkateswara, K. R., Shanker, K. Biosynthesis, characterization and acute oral toxicity studies of synthesized iron oxide nanoparticles using ethanolic extract of Centella asiatica plant. Mater. Lett. 2019, 236, 256-259. https://doi.org/10.1016/j.matlet.2018.10.037

Prabhakar, R.; Samadder, S. R.; Jyotsana. Aquatic and terrestrial weed mediated synthesis of iron nanoparticles for possible application in wastewater remediation. J. Clean.
Prod. 2017, 168, 1201-1210. https://doi.org/10.1016/j.jclepro.2017.09.063

Radini, I. A; Hansan, N.; Malik, M. A.; Khan, Z. Biosynthesis of iron nanoparticles using Trigonella foenumgraecum seed extract for photocatalytic methyl orange dye degradation and antibacterial applications. J. Photochem. Photobiol. B, Biol. 2018, 183, 154-163. https://doi.org/10.1016/j.jphotobiol.2018.04.014

Rahmani, R.; Gharanfoli, M.; Gholamin, M.; Darroudi, M.; Chamani, J.; Sadri, K. Green synthesis of ${ }^{99 m}$ Tc-labeled$\mathrm{Fe}_{3} \mathrm{O}_{4}$ nanoparticles using Quince seeds extract and evaluation of their cytotoxicity and biodistribution in rats. $J$. Mol. Struct. 2019, 1196, 394-402. https://doi.org/10.1016/j.molstruc.2019.06.076

Rahmani, R.; Gharanfoli, M.; Gholamin, M.; Darroudi, M., Chamani, J.; Sadri, K.; Hashemzadeh, A. Plant-mediated synthesis of superparamagnetic iron oxide nanoparticles (SPIONs) using aloe vera and flaxseed extracts and evaluation of their cellular toxicities. Ceram. Int. 2020, 46 (3), 3051-3058 https://doi.org/10.1016/j.ceramint.2019.10.005

Rai, M.; Ingle, A. P.; Gupta, I. R.; Birla, S. S., Yadav, A. P., Abd-Elsalam, K. A. Potential role of biological systems in formation of nanoparticles: mechanism of synthesis and biomedical applications. Curr. Nanosci. 2013, 9 (5), 576587. https://doi.org/10.2174/15734137113099990092

Rajendran, K.; Karunagaran, V.; Mahanty, B.; Sen, S. Biosynthesis of hematite nanoparticles and its cytotoxic effect on HepG2 cancer cells. Int. J. Biol. Macromol. 2015, 74, 376-381. https://doi.org/10.1016/j.ijbiomac.2014.12.028

Rajendran, K.; Sen, S. Optimization of process parameters for the rapid biosynthesis of hematite nanoparticles. $J$. Photochem. Photobiol. B: Biol. 2016, 159, 82-87. https://doi.org/10.1016/j.jphotobiol.2016.03.023

Rajiv, P.; Bavadharani, B.; Kumar, M. N.; Vanathi, P. Synthesis and characterization of biogenic iron oxide nanoparticles using green chemistry approach and evaluating their biological activities. Biocatal. Agric. Biotechnol. 2017, 12, 45-49. https://doi.org/10.1016/j.bcab.2017.08.015

Ramesh, A. V.; Devi, D. R.; Botsa, S. M.; Basavaiah, K. Facile green synthesis of $\mathrm{Fe}_{3} \mathrm{O}_{4}$ nanoparticles using aqueous leaf extract of Zanthoxylum armatum DC. for efficient adsorption of methylene blue. J. Asian Ceram. Soc. 2018, 6 (2),

https://doi.org/10.1080/21870764.2018.1459335

$145-155$.

Rana, P.; Sharma, S.; Sharma, R.; Banerjee, K. Apple pectin supported superparamagnetic $\left(\gamma-\mathrm{Fe}_{2} \mathrm{O}_{3}\right)$ maghemite nanoparticles with antimicrobial potency. Materials Science for Energy Technology 2019, 2 (1), 15-21. https://doi.org/10.1016/j.mset.2018.09.001 
Ranmadugala, D.; Ebrahiminezhad, A.; Manley-Harris, M.; Ghasemi, Y.; Berenjian, A. Reduced biofilm formation in Menaquinone-7 production process by optimizing the composition of the cultivation medium. Trends Pharmac. Sci. 2017, 3 (4), 245-254.

Ratna, D., Padhi, B. S. Pollution due to synthetic dyes toxicity and carcinogenicity studies and remediation. International Journal of Environmental Science 2012, 3 (3), 940-955.

Rizwan, W., Farheen, K., Abdulaziz A., Al-Khedhairy, A. Hematite iron oxide nanoparticles: apoptosis of myoblast cancer cells and their arithmetical assessment. RSC Adv. 2018, 8 , 24750-24759.

https://doi.org/10.1039/C8RA02613K

Roca, A. G.; Gutiérrez, L.; Gavilán, H.; Fortes Brollo, M. E. F.; Veintemillas-Verdaguer, S.; Morales, M. P. Design strategies for shape-controlled magnetic iron oxide nanoparticles. Adv. Drug Deliv. Rev. 2019, 138, 68-104. https://doi.org/10.1016/j.addr.2018.12.008

Rufus, A.; Sreeju, N.; Vilas, V.; Philip, D. Biosynthesis of hematite $\left(\alpha-\mathrm{Fe}_{2} \mathrm{O}_{3}\right)$ nanostructures: Size effects on applications in thermal conductivity, catalysis, and antibacterial activity. J. Mol. Liq. 2017, 242, 537-549. https://doi.org/10.1016/j.molliq.2017.07.057

Rufus, A; Sreeju, N.; Philip, D. Size tunable biosynthesis and luminescence quenching of nanostructured hematite $(\alpha-$ $\mathrm{Fe}_{2} \mathrm{O}_{3}$ ) for catalytic degradation of organic pollutants. $J$. Phys. Chem. Solids 2019, 124, 221-234. https://doi.org/10.1016/j.jpcs.2018.09.026

Ruíz-Baltazar, Á. J.; Reyes-López, S. Y.; MondragónSánchez, M. L.; Robles-Cortés, A. I.; Pérez, R. Eco-friendly synthesis of $\mathrm{Fe}_{3} \mathrm{O}_{4}$ nanoparticles: Evaluation of their catalytic activity in methylene blue degradation by kinetic adsorption models. Results Phys. 2019, 12, 989-995. https://doi.org/10.1016/j.rinp.2018.12.037

Saif, S.; Tahir, A.; Chen, Y. Green synthesis of iron nanoparticles and their environmental applications and implications. Nanomaterials 2016, 6 (11), 209. https://doi.org/10.3390/nano6110209

Salem, D. M. S. A.; Ismail, M. M.; Aly-Eldeen, M. A. Biogenic synthesis and antimicrobial potency of iron oxide $\left(\mathrm{Fe}_{3} \mathrm{O}_{4}\right)$ nanoparticles using algae harvested from the Mediterranean Sea, Egypt. Egypt. J. Aquat. Res. 2019, 45 (3), 197-204. https://doi.org/10.1016/j.ejar.2019.07.002

Sathishkumar, G.; Logeshwaran, V.; Sarathbabu, S.; Jha, P. K.; Jeyaraj, M.; Rajkuberan, C.; Senthilkumar, N.; Sivaramakrishnan, S. Green synthesis of magnetic $\mathrm{Fe}_{3} \mathrm{O}_{4}$ nanoparticles using Couroupita guianensis Aubl. fruit extract for their antibacterial and cytotoxicity activities.
Artif. Cells Nanomed. Biotechnol. 2018, 46 (3), 589-598. https://doi.org/10.1080/21691401.2017.1332635

Sayed, F. N.; Polshettiwar, V. Facile and Sustainable Synthesis of Shaped Iron Oxide Nanoparticles: Effect of Iron Precursor Salts on the Shapes of Iron Oxides. Sci. Rep. 2015, 5, 9733. https://doi.org/10.1038/srep09733

Seabra, A. B.; Pelegrino, M. T.; Haddad, P. S. Antimicrobial Applications of Superparamagnetic Iron Oxide Nanoparticles: Perspectives and Challenges. In Nanostructures for Antimicrobial Therapy; Ficai, A., Grumezescu, A. M., Eds.; Elsevier, 2017; pp 531-550. https://doi.org/10.1016/B978-0-323-46152-8.00024-X

Sharma, D.; Ledwani, L.; Mehrotra, T.; Kumar, N.; Pervaiz, N.; Kumar, R. Biosynthesis of hematite nanoparticles using Rheum emodi and their antimicrobial and anticancerous effects in vitro. J. Photochem. Photobiol. B, Biol. 2020, 206, 111841. https://doi.org/10.1016/j.jphotobiol.2020.111841

Shen, Z.; Wu, A.; Chen, X. Iron oxide nanoparticle-based contrast agents for magnetic resonance imaging. Mol.

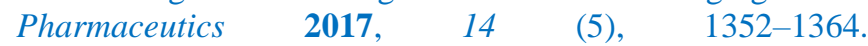
https://doi.org/10.1021/acs.molpharmaceut.6b00839

Singh, P.; Kim, Y.-J.; Zhang, D.; Yang, D.-C. Biological Synthesis of Nanoparticles from Plants and Microorganisms. Trends Biotechnol. 2016, 34 (7), 588-599. https://doi.org/10.1016/j.tibtech.2016.02.006

Sirdeshpande, K. D.; Sridhar, A.; Cholkar, K. M.; Selvaraj, R. Structural characterization of mesoporous magnetite nanoparticles synthesized using the leaf extract of Calliandra haematocephala and their photocatalytic degradation of malachite green dye. Appl. Nanosci. 2018, 8, 675-683. https://doi.org/10.1007/s13204-018-0698-8

Sneha, U.; Karthikeyan, R. Bactericidal activity of ayurvedic formulation against cariogenic microorganisms. Biocatal. Agric. Biotechnol. 2019, 18, 101026. https://doi.org/10.1016/j.bcab.2019.101026

Sorbiun, M.; Mehr, E. S.; Ramazani, A.; Malekzadeh, A. M. Biosynthesis of metallic nanoparticles using plant extracts and evaluation of their antibacterial properties. Nanochem. Res. 2018, 3 (1), 1-16.

Stan, M., Popa, A., Toloman, D.; Dehelean, A.; Lung, I.; Katona, G. Enhanced photocatalytic degradation properties of zinc oxide nanoparticles synthesized by using plant extracts. Mater. Sci. Semicond. Process. 2015, 39, 23-29. https://doi.org/10.1016/j.mssp.2015.04.038

Sulaiman, G. M.; Tawfeeq, A. T.; Naji, A. S. Biosynthesis, characterization of magnetic iron oxide nanoparticles and evaluations of the cytotoxicity and DNA damage of human breast carcinoma cell lines. Artif. Cells Nanomed. 
Biotechnol. 2018, $46 \quad$ (6), 1215-1229. https://doi.org/10.1080/21691401.2017.1366335

Sumera, A.; Tahir, M. B.; Iqbal, T.; Liaqat, A.; Abrar, M. Green synthesis and characterization of novel iron particles by using different extracts. J. Alloys Compd. 2018, 732, 935-944. https://doi.org/10.1016/j.jallcom.2017.10.137

Taghizadeh, S.-M.; Berenjian, A., Taghizadeh, S.; Ghasemi, Y.; Taherpour, A.; Sarmah, A. K.; Ebrahiminezhad, A. Oneput green synthesis of multifunctional silver iron core-shell nanostructure with antimicrobial and catalytic properties. Ind. Crops Prod. 2019, 130 (2019) 230-236. https://doi.org/10.1016/j.indcrop.2018.12.085

Thandapani, K.; Kathiravan, M.; Namasivayam., E.; Padiksan, I. A.; Natesan, G., Tiwari, M., Giovanni, B., Perumal, V. Enhanced larvicidal, antibacterial, and photocatalytic efficacy of $\mathrm{TiO}_{2}$ nanohybrids green synthesized using the aqueous leaf extract of Parthenium hysterophorus. Environ. Sci. Pollut. Res. 2018, 25, 1032810339. https://doi.org/10.1007/s11356-017-9177-0

Thilagavathi, T.; Renuka, R.; Priya, R. S. Bio-synthesis of silver nanoparticles using Punicagranatum (Pomegranate) peel extract: a novel approach towards waste utilization. Int. J. Adv. Sci. Eng. 2016, 3 (1), 234-236.

Toledo, L. A. S.; Rosseto, H. C.; Bruschi M. L. Iron oxide magnetic nanoparticles as antimicrobials for therapeutics. Pharm. Dev. Technol. 2018, 23 (4), 316-323. https://doi.org/10.1080/10837450.2017.1337793

Truskewycz, A.; Shukla, R.; Ball, A. S. Iron nanoparticles synthesized using green tea extracts for the fenton-like degradation of concentrated dye mixtures at elevated temperatures. J. Environ. Chem. Eng. 2016, 4 (4) (Part A), 4409-4417. https://doi.org/10.1016/j.jece.2016.10.008

Vallabani, N. V. S.; Singh, S. Recent advances and future prospects of iron oxide nanoparticles in biomedicine and $\begin{array}{llllll}\text { diagnostics. } & 3 & \text { Biotech 2018, } & \text { 8, } & 279 .\end{array}$ https://doi.org/10.1007/s13205-018-1286-Z

Vasantharaj, S.; Sathiyavimal, S.; Senthilkumar, P.; LewisOscar, F.; Pugazhendhi, A. Biosynthesis of iron oxide nanoparticles using leaf extract of Ruellia tuberosa: antimicrobial properties and their applications in photocatalytic degradation. J. Photochem. Photobiol. B, Biol. 2019, 192, 74-82. https://doi.org/10.1016/j.jphotobiol.2018.12.025

Verma, A.; Mehata, M. S. Controllable synthesis of silver nanoparticles using Neem leaves and their antimicrobial activity. J. Radiat. Res. Appl. Sci. 2016, 9 (1), 109-115. https://doi.org/10.1016/j.jrras.2015.11.001

Vitta, Y.; Figueroa, M.; Calderon, M., Ciangherotti, C. Synthesis of iron nanoparticles from aqueous extract of
Eucalyptus robusta $\mathrm{Sm}$ and evaluation of antioxidant and antimicrobial activity. Materials Science for Energy Technologies 2020, 3, 97-103. https://doi.org/10.1016/j.mset.2019.10.014

Wei, F.; Fang, Z.; Zheng, L.; Tan, L.; Tsang, E. P. Green synthesis of $\mathrm{Fe}$ nanoparticles using Citrus maxima peels aqueous extracts. Mater. Lett. 2016, 185, 384-386. https://doi.org/10.1016/j.matlet.2016.09.029

Woźnica, A.; Dzirba, J.; Mańka, D.; Łabuzek, S. Effects of electron transport inhibitors on iron reduction in Aeromonas hydrophila strain KB1. Anaerobe 2003, 9 (3), 125-130. https://doi.org/10.1016/S1075-9964(03)00059-3

Wu, W.; Wu, Z.; Yu, T.; Jiang, C.; Kim, W.-S. Recent progress on magnetic iron oxide nanoparticles: synthesis, surface functional strategies and biomedical applications. Sci. Technol. Adv. Mater. 2015, 16 (2), 023501. https://doi.org/10.1088/1468-6996/16/2/023501

Yadav, V. K.; Fulekar, M. H. Biogenic synthesis of maghemite nanoparticles $\left(\gamma-\mathrm{Fe}_{2} \mathrm{O}_{3}\right)$ using Tridax leaf extract and its application for removal of fly ash heavy metals $(\mathrm{Pb}$, Cd). Mater. Today: Proc. 2018, 5 (9) (Part 3), 20704-20710. https://doi.org/10.1016/j.matpr.2018.06.454

Yazdani, F.; Seddigh, M. Magnetite nanoparticles synthesized by co-precipitation method: The effects of various iron anions on specifications. Mater. Chem. Phys. 2016, 184, 318-323. https://doi.org/10.1016/j.matchemphys.2016.09.058

Yew, Y. P.; Shameli, K.; Miyake, M.; Khairudin, N. B. B. A.; Mohamad, S. E. B.; Naiki, T.; Lee, K. X. Green biosynthesis of superparamagnetic magnetite $\mathrm{Fe}_{3} \mathrm{O}_{4}$ nanoparticles and biomedical applications in targeted anticancer drug delivery system: A review. Arab. J. Chem. 2020, 13 (1), 2287-2308. https://doi.org/10.1016/j.arabjc.2018.04.013

Zhu, M.; Wang, Y.; Meng, D.; Qin, X.; Diao, G. Hydrothermal synthesis of hematite nanoparticles and their electrochemical properties. J. Phys. Chem. C 2012, 116 (30), 16276-16285. https://doi.org/10.1021/jp304041m 